\title{
Evaluation of Major and Trace Elements in Medicinal Plants
}

\author{
Paulo S. C. Silva, * Lucilaine S. Francisconi and Rodolfo D. M. R. Gonçalves \\ Instituto de Pesquisas Energéticas e Nucleares, CNEN/IPEN, Av Prof. Lineu Prestes, 2242, \\ Cidade Universitária, CP 11049, 05508-000 São Paulo-SP, Brazil
}

\begin{abstract}
This study presents the elemental concentration results obtained from 59 medicinal plants used in Brazil, determined by instrumental neutron activation analysis (INAA), inductively coupled plasma-optical emission spectrometry (ICP OES) and cold vapor atomic absorption spectrometry (CV AAS). The selected plant species were chosen from the Brazilian National Agency for Sanitary Vigilance (ANVISA) list of herbs recommended for utilization by the Public System of Health in Brazil (SUS). The results showed that high levels of foreign matter were found in almost $50 \%$ of the analyzed samples. The concentration of the elements varied in a wide range, although, generally in accordance with values found in literature. High concentrations of $\mathrm{Ba}, \mathrm{Cr}$, $\mathrm{Fe}, \mathrm{Hg}$, Se and $\mathrm{Ni}$ were found in some samples. The enrichment factor indicated that potentially hazardous elements can be accumulated mainly in the bark of the plants, possibly indicating an anthropogenic contribution.
\end{abstract}

Keywords: medicinal plant, major element, trace element, NAA, ICP OES, CV AAS

\section{Introduction}

Medicinal plants are widely used all over the world and, according to the World Health Organization (WHO), for many millions of people, traditional medicines, including herbal medicines, are the main source of health care and, sometimes, the only source of care. ${ }^{1}$ Their demand is growing worldwide both in developing and industrialized countries, as a complementary way to treat and to prevent diseases..$^{2-5}$ The growing interest in this type of health care has also been accompanied by effectiveness, availability, preservation, quality, safety and regulation concerns. Therefore, the World Health Organization has also set out the need for quality control standards of medicinal plants including classification, botanical identification, active compounds determination and contaminant identification, following the recommendation of the World Health Assembly. ${ }^{6}$ As a global strategy for traditional and complementary medicine, the WHO has stimulated the State Members to develop public policies in order to include herbal medicines and phytotherapics in their public health system. ${ }^{1}$

Besides being used for the treatment of diseases, the medicinal plants are also used as dietary supplements once they are found to be rich in one or more elements.

*e-mail: pscsilva@ipen.br
Elemental content in medicinal plants can vary in a wide range, depending on factors such as soil geochemical characteristics, atmospheric deposition and the ability of each plant species to selectively accumulate some of them. ${ }^{7,8}$ Nevertheless, medicinal herbs can be easily contaminated during growth, development and processing.

The determination of major, minor and trace elements in medicinal plants and their impacts on human health are also of great importance due to the growth of environmental pollution that directly affects the plants and, therefore, their phytotherapics. Besides, being essential in the living system, the elements can be at the same time toxic, when at concentrations beyond those necessary for metabolic functions. ${ }^{9-11}$

Brazil possesses one of the greatest vegetal genetic diversity of the world, accounting for approximately $20 \%$ of all known living species globally; ${ }^{12}$ over one thousand species of plants are estimated to be used as medicine by the population. However, to be used by the Public System of Health, the National Agency for Sanitary Vigilance establishes that toxicological risks and the absence of toxic chemical substances must be within safe proven limits.

Despite the richness of the Brazilian flora, the extensive use of medicinal plants by the population and the importance exerted by trace elements in the human metabolism ${ }^{13}$ lead to a consensus that scientific studies on elemental concentrations in medicinal plants are 
insufficient in view of the importance of these results, considering individual and social consequences.

Therefore, the objective of this paper was to determine the content of inorganic constituents in herbal medicines: moisture, ash, insoluble acid ash and the element concentrations of As, $\mathrm{Ba}, \mathrm{Br}, \mathrm{Ca}, \mathrm{Cl}, \mathrm{Co}, \mathrm{Cr}, \mathrm{Cs}, \mathrm{Fe}, \mathrm{Hf}, \mathrm{K}$, $\mathrm{Na}, \mathrm{Mg}, \mathrm{Mn}, \mathrm{Rb}, \mathrm{Sb}, \mathrm{Sc}, \mathrm{Se}, \mathrm{Ti}, \mathrm{V}$ and $\mathrm{Zn}$, by instrumental neutron activation analysis (INAA); $\mathrm{Cd}, \mathrm{Cu}, \mathrm{Ni}$ and $\mathrm{Pb}$ by inductively coupled plasma-optical emission spectrometry (ICP OES) and $\mathrm{Hg}$ by cold vapor atomic absorption spectrometry (CV AAS). The results were used to verify the quality of the products, the range of concentrations found in plants commonly used in folk medicine and whether these concentrations are within the safe limits stated by reference standards of intake, when existent. To verify the distribution pattern of the elemental concentrations, statistical analysis (correlation coefficient, cluster analysis and principal component analysis) was also applied to the results. As far as we know, the concentration of the elements proposed to be determined in this study has not been determined before, for the majority of the plants.

\section{Experimental}

Plant species were chosen from a list of 66 herbs recommended by the Brazilian National Agency for Sanitary Vigilance (ANVISA) to be used in the Public Health System. From this list, 59 species, in the form of dried material, were found in specialized pharmacies and drugstores. The plant names, used parts and medicinal applications are listed on Table 1.

\section{Search for foreign matter}

Foreign matter, as defined by WHO, is any part of the medicinal plant material or materials other than those named with the limits specified for the plant material concerned; any organism, part or product of an organism, other than that named in the specification and description of the plant material concerned or; any mineral admixtures not adhering to the medicinal plant materials, such as soil, stones, sand, and dust. ${ }^{14}$

For foreign matter determination, the whole sample

Table 1. Plants, scientific name (Brazilian popular name), used part to extract preparation, medicinal indication, dosage and mode of preparation according to ANVISA

\begin{tabular}{|c|c|c|c|c|c|}
\hline \multirow[b]{2}{*}{ Scientific name } & \multirow[b]{2}{*}{ Used part } & \multirow[b]{2}{*}{ Indication } & \multirow{2}{*}{$\begin{array}{c}\text { Dosage / } \\
\text { (tea-cups per day) }\end{array}$} & \multicolumn{2}{|c|}{ Preparation } \\
\hline & & & & $\begin{array}{l}\text { Type of preparation } \\
\text { (mass used) /g }\end{array}$ & $\begin{array}{l}\text { Volume of } \\
\text { water / mL }\end{array}$ \\
\hline $\begin{array}{l}\text { Achillea millefolium } \mathrm{L} . \\
\text { ("aquiléia") }\end{array}$ & shoots & $\begin{array}{c}\text { lack of appetite, fever, inflammation and } \\
\text { cramping }\end{array}$ & $3-4$ & infusion (1-2) & 150 \\
\hline $\begin{array}{l}\text { Achyrocline satureioides } \\
\text { Lam. DC. ("macela") }\end{array}$ & inflorescence & $\begin{array}{l}\text { poor digestion and intestinal cramps, mild } \\
\text { sedative, and anti-inflammatory }\end{array}$ & 4 & infusion (1.5) & 150 \\
\hline $\begin{array}{l}\text { Aesculus hippocastanum } \\
\text { L. ("castanheiro-da- } \\
\text { índia") }\end{array}$ & seeds in shell & $\begin{array}{l}\text { capillary fragility, venous insufficiency } \\
\text { (varicose veins and hemorrhoids) }\end{array}$ & 2 , after meals & decoction (1.5) & 150 \\
\hline $\begin{array}{l}\text { Ageratum conyzoides L. } \\
\text { ("mentrasto") }\end{array}$ & shoots without flowers & $\begin{array}{l}\text { joint pain (arthritis, arthrosis) and } \\
\text { rheumatism }\end{array}$ & $2-3$ & infusion (2-3) & 150 \\
\hline $\begin{array}{l}\text { Allium sativum } \mathrm{L} . \\
\text { (“cebola") }\end{array}$ & bulb & high cholesterol, as expectorant & 2 , before meals & maceration $(0.5)$ & 30 \\
\hline $\begin{array}{l}\text { Anacardium occidentale } \\
\text { L. ("cajueiro") }\end{array}$ & under bark & noninfectious diarrhea & $3-4$ & decoction (4.5) & 150 \\
\hline $\begin{array}{l}\text { Arctium lappa } \mathrm{L} . \\
\text { ("bardana") }\end{array}$ & roots & $\begin{array}{l}\text { dyspepsia, diuretic and anti-inflammatory } \\
\text { such as the joint pain }\end{array}$ & $2-3$ & decoction (2) & 150 \\
\hline $\begin{array}{l}\text { Arnica montana L. } \\
\text { (“arnica Montana") } \\
\end{array}$ & flowers & $\begin{array}{c}\text { trauma, bruises, sprains, swelling due to } \\
\text { fractures and sprains }\end{array}$ & $\begin{array}{c}\text { compress ( } 2 \text { to } 3 \\
\text { times daily) }\end{array}$ & infusion (3) & 150 \\
\hline $\begin{array}{l}\text { Baccharis trimera } \\
\text { (Less.) DC. ("carqueja") }\end{array}$ & shoots & dyspepsia & $2-3$ & infusion (2.5) & 150 \\
\hline $\begin{array}{l}\text { Bidens pilosa } \mathrm{L} . \\
\text { ("picão preto") }\end{array}$ & leaves & jaundice & 4 & infusion (2) & 150 \\
\hline $\begin{array}{l}\text { Calendula officinalis } \mathrm{L} . \\
\text { ("calendula") }\end{array}$ & flowers & $\begin{array}{l}\text { inflammations and injuries, bruises and } \\
\text { burns }\end{array}$ & $\begin{array}{l}\text { compress ( } 3 \text { times } \\
\text { daily) }\end{array}$ & infusion (1-2) & 150 \\
\hline $\begin{array}{l}\text { Caesalpinia ferrea Mart. } \\
\text { ex Tul. ("pau-ferro") }\end{array}$ & beans & $\begin{array}{l}\text { injuries as hemostatic astringent and } \\
\text { antiseptic healing }\end{array}$ & $\begin{array}{l}\text { compress (2-3 times } \\
\text { daily) }\end{array}$ & decoction (7.5) & 150 \\
\hline $\begin{array}{l}\text { Casearia sylvestris Sw. } \\
\text { ("guaçatonga") }\end{array}$ & leaves & $\begin{array}{l}\text { pain and injuries, as an antiseptic and } \\
\text { healing topic }\end{array}$ & $3-4$ & infusion (2-4) & 150 \\
\hline
\end{tabular}


Table 1. Plants, scientific name (popular name), used part to extract preparation, medicinal indication, dosage and mode of preparation according to ANVISA (cont.)

\begin{tabular}{|c|c|c|c|c|c|}
\hline \multirow[b]{2}{*}{ Scientific name } & \multirow[b]{2}{*}{ Used part } & \multirow[b]{2}{*}{ Indication } & \multirow{2}{*}{$\begin{array}{c}\text { Dosage / } \\
\text { (tea-cups per day) }\end{array}$} & \multicolumn{2}{|c|}{ Preparation } \\
\hline & & & & $\begin{array}{l}\text { Type of preparation } \\
\text { (mass used) /g }\end{array}$ & $\begin{array}{l}\text { Volume of } \\
\text { water / } \mathrm{mL}\end{array}$ \\
\hline $\begin{array}{l}\text { Cinnamomum verum J. } \\
\text { Presl. ("canela") }\end{array}$ & bark & $\begin{array}{l}\text { lack of appetite, mild cramping, flatulence } \\
\text { and feeling of fullness }\end{array}$ & $2-6$ & decoction $(0.5-2)$ & 150 \\
\hline $\begin{array}{l}\text { Citrus aurantium } \mathrm{L} . \\
\text { ("laranja amarga") }\end{array}$ & flowers & $\begin{array}{l}\text { mild cases of anxiety and insomnia, } \\
\text { sedative }\end{array}$ & $1-2$, before bedtime & $\begin{array}{l}\text { maceration, (1-2) } \\
(3-4 \mathrm{~h})\end{array}$ & 150 \\
\hline $\begin{array}{l}\text { Cordia verbenacea DC. } \\
\text { ("erva-baleeira") }\end{array}$ & leaves & inflammation in bruises and pain & 3 & infusion (3) & 150 \\
\hline $\begin{array}{l}\text { Curcuma longa } \mathrm{L} . \\
\text { (“açafrão-da-terra”) }\end{array}$ & rhizomes & dyspepsia, anti-inflammatory & $1-2$ & decoction (1.5) & 150 \\
\hline $\begin{array}{l}\text { Cymbopogon citratus } \\
\text { (DC.) Stapf. } \\
\text { (“capim-limão”) }\end{array}$ & leaves & $\begin{array}{l}\text { intestinal and uterine cramping, mild } \\
\text { anxiety cases, insomnia, sedative }\end{array}$ & $2-3$ & infusion (1-3) & 150 \\
\hline $\begin{array}{l}\text { Echinodorus } \\
\text { macrophyllus (Kunth) } \\
\text { Micheli ("chapéu-de- } \\
\text { couro") }\end{array}$ & leaves & edema by fluid retention and inflammation & 3 & infusion (1) & 150 \\
\hline $\begin{array}{l}\text { Equisetum arvense } \mathrm{L} . \\
\text { ("cavalinha") }\end{array}$ & shoots & edema by fluid retention and inflammation & $2-4$ & infusion (3) & 150 \\
\hline $\begin{array}{l}\text { Erythrina verna Vell. } \\
\text { (mulungu) }\end{array}$ & bark & $\begin{array}{l}\text { mild cases of anxiety and insomnia, } \\
\text { sedative }\end{array}$ & $2-3$ & decoction (4-6) & 150 \\
\hline $\begin{array}{l}\text { Eucalyptus globulus } \\
\text { Labill. ("eucalipto") }\end{array}$ & leaves & $\begin{array}{l}\text { colds and flus to clear airway as an adjunct } \\
\text { in the treatment of bronchitis and asthma }\end{array}$ & $\begin{array}{c}\text { inhalation } 2 \text { times } \\
\text { per day }\end{array}$ & infusion (2) & 150 \\
\hline $\begin{array}{l}\text { Eugenia uniflora } \mathrm{L} . \\
\text { ("pitanga") }\end{array}$ & leaves & noninfectious diarrhea & $\begin{array}{l}1 \text { cup after making } \\
\text { the feces (maximum } \\
10 \text { times } \text { per } \text { day) }\end{array}$ & infusion (3) & 150 \\
\hline $\begin{array}{l}\text { Glycyrrhiza glabra L. } \\
\text { (“alcaçuz") }\end{array}$ & root & coughs, colds and flus & $3-4$ & infusion (4.5) & 150 \\
\hline $\begin{array}{l}\text { Hamamelis virginiana } \mathrm{L} . \\
\text { ("amamélis") }\end{array}$ & bark & $\begin{array}{c}\text { skin inflammations and mucous } \\
\text { membranes, hemorrhoids }\end{array}$ & $\begin{array}{l}\text { compress (2-3 times } \\
\text { daily) }\end{array}$ & decoction (3-6) & 150 \\
\hline $\begin{array}{l}\text { Harpagophytum } \\
\text { procumbens (Burch.) } \\
\text { DC. ex Meisn } \\
\text { (“garra-do-diabo") } \\
\end{array}$ & root & joint pain (arthritis, arthrosis, arthralgia) & $2-3$ & infusion (1) & 150 \\
\hline $\begin{array}{l}\text { Illicium verum Hook F. } \\
\text { (“anis estrelado") }\end{array}$ & fruit & bronchitis, expectorant & $3-4$ & infusion (1.5) & 150 \\
\hline $\begin{array}{l}\text { Lippia sidoides Cham. } \\
\text { ("alecrim-pimenta") } \\
\end{array}$ & leaves & gargles, mouthwashes and rinses & apply 2-3 daily & infusion (2-3) & 150 \\
\hline $\begin{array}{l}\text { Malva sylvestris } \mathrm{L} . \\
\text { ("malva") }\end{array}$ & leaves and flowers & respiratory expectorants & 4 & infusion (2) & 150 \\
\hline $\begin{array}{l}\text { Matricaria recutita } \mathrm{L} . \\
\text { ("camomila") }\end{array}$ & flowers & $\begin{array}{l}\text { intestinal cramps, mild anxiety cases, mild } \\
\text { tranquilizer }\end{array}$ & $3-4$ & infusion (3) & 150 \\
\hline $\begin{array}{l}\text { Maytenus ilicifolia } \text { Mart. } \\
\text { ex Reissek } \\
\text { (“espinheira-santa”) }\end{array}$ & leaves & $\begin{array}{l}\text { dyspepsia, heartburn and gastritis, adjuvant } \\
\text { ulcer prevention treatment }\end{array}$ & $3-4$ & infusion (1-2) & 150 \\
\hline $\begin{array}{l}\text { Melissa officinalis L. } \\
\text { ("melissa") }\end{array}$ & inflorescence & $\begin{array}{l}\text { abdominal cramps, mild anxiety and } \\
\text { insomnia cases, mild tranquilizer }\end{array}$ & $2-3$ & infusion (2-4) & 150 \\
\hline $\begin{array}{l}\text { Mentha } \times \text { piperita } \mathrm{L} . \\
\text { ("hortelã-pimenta") }\end{array}$ & leaves and inflorescence & colic, flatulence, liver problems & $2-4$ & infusion (1.5) & 150 \\
\hline $\begin{array}{l}\text { Mentha pulegium } \mathrm{L} . \\
\text { ("poejo") }\end{array}$ & shoots & $\begin{array}{c}\text { respiratory expectorant, appetite stimulant, } \\
\text { digestive disturbances, gastrointestinal } \\
\text { spasms } \\
\end{array}$ & $\begin{array}{l}2-3 \text {, during the } \\
\text { meals }\end{array}$ & infusion (1) & 150 \\
\hline $\begin{array}{l}\text { Mikania glomerata } \\
\text { Spreng. ("guaco") }\end{array}$ & leaves & $\begin{array}{l}\text { colds and flus, allergic and infectious } \\
\text { bronchitis, expectorant }\end{array}$ & 3 & infusion (3) & 150 \\
\hline
\end{tabular}


Table 1. Plants, scientific name (popular name), used part to extract preparation, medicinal indication, dosage and mode of preparation according to ANVISA (cont.)

\begin{tabular}{|c|c|c|c|c|c|}
\hline \multirow[b]{2}{*}{ Scientific name } & \multirow[b]{2}{*}{ Used part } & \multirow[b]{2}{*}{ Indication } & \multirow[b]{2}{*}{$\begin{array}{c}\text { Dosage / } \\
\text { (tea-cups per day) }\end{array}$} & \multicolumn{2}{|c|}{ Preparation } \\
\hline & & & & $\begin{array}{l}\text { Type of preparation } \\
\text { (mass used) /g }\end{array}$ & $\begin{array}{l}\text { Volume of } \\
\text { water } / \mathrm{mL}\end{array}$ \\
\hline $\begin{array}{l}\text { Momordica charantia } \mathrm{L} . \\
\text { (melão-de-São-Caetano) }\end{array}$ & fruit, and seeds & dermatitis and scabies & $\begin{array}{l}\text { apply to affected } \\
\text { areas } 2 \text { times per } \\
\text { day } \\
\end{array}$ & decoction (5) & 1000 \\
\hline $\begin{array}{l}\text { Passiflora alata Curtis } \\
\text { ("maracujá-doce") }\end{array}$ & leaves & $\begin{array}{l}\text { mild anxiety and insomnia, mild } \\
\text { tranquilizer }\end{array}$ & $1-2$ & infusion (3) & 150 \\
\hline $\begin{array}{l}\text { Passiflora incarnata } \mathrm{L} . \\
\text { ("maracujá") }\end{array}$ & shoots & $\begin{array}{l}\text { mild anxiety and insomnia cases, mild } \\
\text { tranquilizer }\end{array}$ & $3-4$ & infusion (3) & 150 \\
\hline $\begin{array}{l}\text { Paullinia cupana Kunth } \\
\text { (guarana) }\end{array}$ & seeds & fatigue, stimulant & $\begin{array}{l}\text { used pure or diluted } \\
\text { in water }\end{array}$ & $\begin{array}{l}0.5-2 \mathrm{~g} \text { of the } \\
\text { powder }\end{array}$ & \\
\hline $\begin{array}{l}\text { Peumus boldus Molina } \\
\text { ("boldo do Chile") }\end{array}$ & leaves & dyspepsia, choleretic and cholagogue & 2 & infusion (1-2) & 150 \\
\hline $\begin{array}{l}\text { Phyllanthus niruri } \mathrm{L} . \\
\text { ("quebra-pedra") }\end{array}$ & shoots & elimination of small kidney stones & $2-3$ & infusion (3) & 150 \\
\hline $\begin{array}{l}\text { Pimpinela anisum } \mathrm{L} . \\
\text { ("erva-doce") }\end{array}$ & fruit & dyspepsia, gastrointestinal cramps & 3 & decoction (1.5) & 150 \\
\hline $\begin{array}{l}\text { Plantago major } \mathrm{L} . \\
\text { ("tanchagem") }\end{array}$ & leaves & inflammations of the mouth and pharynx & $\begin{array}{c}\text { mouthwashes and } \\
\text { gargles } 3 \text { times per } \\
\text { day }\end{array}$ & infusion (6-9) & 150 \\
\hline $\begin{array}{l}\text { Polygonum punctatum } \\
\text { Elliot (“erva-de-bicho") }\end{array}$ & shoots & varicose veins and varicose ulcers & $\begin{array}{c}\text { apply on the } \\
\text { affected site } 3 \text { times } \\
\text { a day }\end{array}$ & infusion (3) & 150 \\
\hline $\begin{array}{l}\text { Psidium guajava } \mathrm{L} . \\
\text { (guava) }\end{array}$ & young leaves & noninfectious diarrhea & $\begin{array}{l}1 \text { cup after making } \\
\text { the feces (maximum } \\
10 \text { times per } \text { day) }\end{array}$ & infusion (2) & 150 \\
\hline $\begin{array}{l}\text { Punica granatum } \mathrm{L} . \\
\text { ("romã") }\end{array}$ & fruit peel & $\begin{array}{l}\text { inflammation and infection of the mouth } \\
\text { and pharynx anti-inflammatory }\end{array}$ & $\begin{array}{c}\text { mouthwashes and } \\
\text { gargles } 3 \text { times per } \\
\text { day }\end{array}$ & decoction (6) & 150 \\
\hline $\begin{array}{l}\text { Rhamnus purshiana DC. } \\
\text { (cáscara sagrada) }\end{array}$ & bark & eventual intestinal constipation & $\begin{array}{l}1 / 2 \text { tea-cup per day } \\
\text { before bedtime }\end{array}$ & decoction, $(0.5)$ & 150 \\
\hline $\begin{array}{l}\text { Rosmarinus officinalis L. } \\
\text { ("alecrim") }\end{array}$ & leaves & $\begin{array}{c}\text { circulatory disorders, antiseptic and } \\
\text { healing }\end{array}$ & $\begin{array}{l}\text { apply to the affected } \\
\text { area } 2 \text { per day }\end{array}$ & infusion (3-6) & 150 \\
\hline $\begin{array}{l}\text { Salvia officinalis L. } \\
\text { ("sálvia") }\end{array}$ & leaves & dyspepsia and excessive sweating & $2-3$ & infusion (1.5-2) & 150 \\
\hline $\begin{array}{l}\text { Sambucus nigra } \mathrm{L} . \\
\text { (“sabugueiro”) }\end{array}$ & flowers & colds and flus & $2-3$ & infusion (3) & 150 \\
\hline $\begin{array}{l}\text { Schinus terebinthifolius } \\
\text { Raddi ("aroeira") }\end{array}$ & bark & $\begin{array}{l}\text { vaginal inflammation, leukorrhea, } \\
\text { hemostatic, astringent and healing }\end{array}$ & $\begin{array}{l}\text { compress, baths } \\
\text { (2 times daily) }\end{array}$ & decoction (1) & 1000 \\
\hline $\begin{array}{l}\text { Senna alexandrina Mill. } \\
\text { (sene) }\end{array}$ & fruit and folioles & eventual intestinal constipation & 1 , before bedtime & decoction (1) & 150 \\
\hline $\begin{array}{l}\text { Solanum paniculatum } \mathrm{L} . \\
\text { ("jurubeba") }\end{array}$ & whole plant & dyspepsia & $3-4$ & infusion (1) & 150 \\
\hline $\begin{array}{l}\text { Stryphnodendron } \\
\text { adstrigens (Mart.) } \\
\text { Coville. ("barbatimão") }\end{array}$ & bark & $\begin{array}{l}\text { injuries, healing and topical antiseptic on } \\
\text { the skin, oral mucosa and genital }\end{array}$ & $\begin{array}{l}\text { compress, baths } \\
\text { (2-3 times daily) }\end{array}$ & decoction (3) & 1000 \\
\hline $\begin{array}{l}\text { Taraxacum officinale } \\
\text { F. H. Wigg ("dente-de- } \\
\text { leão") }\end{array}$ & whole plant & $\begin{array}{c}\text { dyspepsia, appetite stimulant and as a } \\
\text { diuretic }\end{array}$ & 3 & decoction (3-4) & 150 \\
\hline $\begin{array}{l}\text { Uncaria tomentosa } \\
\text { (Willd. ex Roem. \& } \\
\text { Schult.) DC. } \\
\text { ("unha-de-gato") } \\
\end{array}$ & bark & $\begin{array}{l}\text { joint pain (arthritis and osteoarthritis) and } \\
\text { acute muscle anti-inflammatory }\end{array}$ & $2-3$ & decoction $(0.5)$ & 150 \\
\hline $\begin{array}{l}\text { Vernonia polyanthes } \\
\text { Less. (“assa-peixe") }\end{array}$ & leaves & pain and dyspepsia & 3 , before meals & infusion (3) & 150 \\
\hline $\begin{array}{l}\text { Zingiber officinale } \\
\text { Roscoe ("gengibre") }\end{array}$ & rhizome & $\begin{array}{c}\text { sickness, nausea and vomiting of } \\
\text { pregnancy, postoperative motion, dyspepsia }\end{array}$ & $2-4$ & decoction $(0.5-1)$ & 150 \\
\hline
\end{tabular}


pack, after being precisely weighed, was spread above a white and clean surface and any strange material was removed. Particles of soil, stone, sand, insects or parts of insects, as well as any part of the plant other than that indicated for use was considered foreign matter. Signs of mould, abnormal odor, discoloration, slime and deterioration were, also, searched. ${ }^{14}$

\section{Moisture determination}

For moisture determination, approximately $10 \mathrm{~g}$ of each sample was weighed in analytical balance and let to stand in an oven at temperature varying from 100 to $105^{\circ} \mathrm{C}$, until constant weight, being weighed after cooling in a desiccator. ${ }^{14}$

\section{Ash}

The inorganic ash determination was done by calcinating the sample used in the moisture determination in a muffle, at $900^{\circ} \mathrm{C}$, for 2 hours. The residue was allowed to cool in a desiccator and weighed.

\section{Insoluble acid ash}

The residue obtained in the inorganic ash determination was then treated with $25 \mathrm{~mL}$ of ultrapure concentrated $\mathrm{HNO}_{3}$, filtered in paper filter. The paper was washed with $5 \mathrm{~mL}$ of ultra-pure water and let to dry in a ventilated furnace oven. The insoluble acid ash amount was determined by the difference in the filter paper weigh before and after the filtration.

\section{INAA measurement}

Instrumental neutron activation analysis (INAA) is a sensitive and multielemental technique, which has been frequently used to evaluate inorganic elemental content in medicinal plants. ${ }^{15-17}$

For the INAA determinations, the raw plant samples were dried in a ventilated furnace oven at 40 to $45^{\circ} \mathrm{C}$ and then powdered to a grain size lower than $0.150 \mathrm{~mm}$. Approximately $150 \mathrm{mg}$ of the powdered samples and $100 \mathrm{mg}$ of powdered reference materials (United States Geological Survey-USGS-Rhyolite, Glass Mountain, RGM-2 and Syenite, Table Mountain, STM-2) were sealed in pre-cleaned polyethylene bags. Synthetic standards were also prepared by pipetting convenient aliquots of standard solutions (SPEX Certiprep Inc., USA) using Milli-Q water $18.2 \mathrm{M} \Omega \mathrm{cm}$ at $25^{\circ} \mathrm{C}$ (Millipore Corporation, USA), onto small filter paper sheets. The plant samples, reference materials and synthetic standards were irradiated for $8 \mathrm{~h}$, in the IEA-R1 nuclear reactor at IPEN (Instituto de Pesquisas Energéticas e Nucleares, Brazil), for As, Ba, Br, Ca, Co, $\mathrm{Cr}, \mathrm{Cs}, \mathrm{Fe}, \mathrm{Hf}, \mathrm{K}, \mathrm{Na}, \mathrm{Rb}, \mathrm{Sb}$, Sc, Se, and Zn determination and for $20 \mathrm{~s}$ for $\mathrm{Cl}, \mathrm{Mg}, \mathrm{Mn}$, Ti and $\mathrm{V}$ determination under a thermal neutron flux of $1-5 \times 10^{12} \mathrm{~cm}^{-2} \mathrm{~s}^{-1}$. The counting was done at different time frames, depending on the radionuclide half-live produced during the irradiation: this process was performed by Gamma Spectrometry, using an EG\&G Ortec Ge Highpure Gamma Spectrometer detector (AMETEK Inc., USA) and associated electronics, with a resolution of 0.88 and $1.90 \mathrm{keV}$ for ${ }^{57} \mathrm{Co}$ and ${ }^{60} \mathrm{Co}$, respectively. The analysis of the data was done by using an in-house gamma ray software, VISPECT program, to identify the gamma-ray peaks. The methodology precision and accuracy were verified by using, as Standard Reference Materials (SRM) from the National Institute of Standards and Technology (NIST), apple leaves (NIST SRM 1515), peach leaves (NIST SRM1547) and tomato leaves (NIST SRM1573a).

\section{ICP OES and CV AAS measurement}

For the determination of $\mathrm{Cd}, \mathrm{Cu}, \mathrm{Ni}$ and $\mathrm{Pb}$, approximately, $300 \mathrm{mg}$ of each dried and powdered sample were dissolved with a mixture of concentrated acids $\left(\mathrm{HNO}_{3}, \mathrm{HCl}, \mathrm{HClO}_{4}\right)$ and $\mathrm{H}_{2} \mathrm{O}_{2}$; all reagents were of analytical grade, and digested in a MARS 5 (CEM Corporation, USA) microwave closed system. After the digestion process, the samples were allowed to cool and filtered. The concentrations were determined by using a Spectro Flame M120E ICP OES (AMETEK Inc., USA). For the determination of $\mathrm{Hg}$ by $\mathrm{CV}$ AAS, the same digested samples were measured by using a PerkinElmer AANALYST 800 instrument. The methodology precision and accuracy were verified by using the reference materials apple leave (NIST SRM 1515) and peach leave (NIST SRM1547). The detailed methodology for ICP OES and CV AAS measurements, as well as the calibration curves used for the concentrations in all the samples are presented in the literature. ${ }^{18}$

\section{Results}

Table 2 shows the percentages of foreign matter, moisture, ash, insoluble acid ash and the permitted amounts of these parameters, according to the Brazilian Pharmacopeia. ${ }^{19}$

Unless specified elsewhere, the total permitted foreign matter is $2 \%$ in the dried raw material. Among the analyzed samples, $47 \%$ showed foreign matter content above the recommended levels, with the highest values over $60 \%$ 
Table 2. Foreign matter quantities (FM), permitted foreign matter (PFM), moisture (M), permitted moisture, permitted moisture (PM) total ash (TA), permitted total ash (PTA) insoluble acid ash (IAA) and permitted insoluble acid ash (PIAA)

\begin{tabular}{|c|c|c|c|c|c|c|c|c|}
\hline Scientific name & $\mathrm{FM} / \%$ & PFM / \% & $\mathrm{M} / \%$ & $\mathrm{PM} / \%$ & $\mathrm{TA} / \%$ & $\mathrm{PTA} / \%$ & IAA / \% & PIAA / \% \\
\hline Achillea millefolium & 0.04 & 2 & 8.2 & $8-14$ & 5.4 & - & 1.6 & - \\
\hline Achyrocline satureioides & 7.3 & 2 & 5.7 & 10 & 3.5 & 8 & 0.5 & - \\
\hline Aesculus hippocastanum & 0.1 & 2 & 8.6 & 10 & 2.2 & 4 & 0.4 & - \\
\hline Agerantum conyzoides & 6.5 & 2 & 7.5 & $8-14$ & 9.1 & - & 6.6 & - \\
\hline Allium sativum & 0.1 & 5 & 9.2 & 7 & 3.2 & 5 & 0.1 & - \\
\hline Anacardium occidentales & - & 2 & 8.2 & $8-14$ & 0.7 & 2.6 & 1.1 & - \\
\hline Arctium lappa & 2.6 & 2 & 7.5 & $8-14$ & 11.0 & 6 & 1.6 & - \\
\hline Arnica montana & 4.2 & 5 & 8.5 & $8-14$ & 6.7 & 10 & 1.3 & - \\
\hline Baccharis trimera & 2.3 & 2 & 7.9 & 12 & 2.6 & 8 & 0.8 & - \\
\hline Bidens pilosa & 5.4 & 2 & 9.9 & $8-14$ & 6.6 & - & 0.4 & - \\
\hline Caesalpinia ferrea & - & 2 & 6.9 & $8-14$ & 3.7 & - & 0.8 & - \\
\hline Calendula officinalis & 0.4 & 3 & 8.0 & 12 & 6.4 & 10 & 0.8 & - \\
\hline Casearia sylvestris & 10.1 & 3 & 7.4 & 12 & 5.4 & 8 & 0.6 & 2 \\
\hline Cinnamomum verum & 0.03 & 2 & 6.1 & $8-14$ & 24.9 & 5 & 1.7 & - \\
\hline Citrus auranrium & - & 2 & 12.2 & 10 & 2.2 & 7 & 0.5 & - \\
\hline Cordia verbanacea & 15.3 & 2 & 6.4 & $8-14$ & 3.3 & - & 1.8 & - \\
\hline Curcuma longa & - & 2 & 8.8 & 12 & 4.3 & 8 & 0.9 & - \\
\hline Cymbopogon citratus & 3.6 & 1 & 8.2 & 11 & 6.3 & 9 & 1.0 & - \\
\hline Cynara scolymus & 6.6 & 2 & 8.5 & 12 & 7.4 & 20 & 2.3 & - \\
\hline Echinodorus macrophyllus & 1.9 & 2 & 8.1 & 9 & 7.1 & 12 & 2.3 & - \\
\hline Equisetum arvense & 0.3 & 2 & 8.7 & $8-14$ & 5.3 & - & 3.5 & - \\
\hline Eryhrina verna & - & 5 & 7.2 & 12 & 4.9 & 5 & 1.5 & - \\
\hline Eucalyptus globulus & 30.4 & 3 & 4.0 & $8-14$ & 3.1 & 5 & 0.1 & - \\
\hline Eugenia uniflora & 60.2 & 2 & 5.3 & 10 & 3.5 & 11 & 0.8 & - \\
\hline Glycyrrhiza glaba & - & 2 & 8.0 & 10 & 1.0 & 6.5 & 1.2 & 2.5 \\
\hline Hamamelis virginiana & 7.6 & 2 & 6.5 & 5 & 4.2 & 7 & 0.7 & 2 \\
\hline Harpagophytum procumbens & 0.04 & 2 & 9.8 & $8-14$ & 8.8 & - & 4.7 & - \\
\hline Illicium verum & 1.4 & 2 & 11.6 & 7 & 36.1 & 6 & 0.2 & - \\
\hline Lippia sidoides & - & 2 & 4.5 & $8-14$ & 4.6 & - & 1.8 & - \\
\hline Malva sylvestris & 5.3 & 2 & 6.7 & $8-14$ & 6.8 & 16 & 0.6 & - \\
\hline Matricaria recutita & 1.9 & 5 & 7.9 & $8-14$ & 5.9 & 14 & 0.1 & - \\
\hline Maytenus ilicifolia & 60.8 & 2 & 6.8 & 12 & 7.2 & 8 & 1.7 & - \\
\hline Melissa officinalis & 0.3 & 10 & 6.8 & 10 & 5.6 & 12 & 1.7 & - \\
\hline Mentha piperita & - & 10 & 7.5 & 12 & 10.1 & 15 & 0.5 & - \\
\hline Mentha pulegium & 15.2 & 2 & 7.5 & $8-14$ & 9.0 & - & 3.6 & - \\
\hline Mikania glomerata & 52.8 & 2 & 6.2 & $8-14$ & 8.5 & - & 3.7 & - \\
\hline Momordica charantia & 8.4 & 2 & 6.4 & $8-14$ & 5.1 & - & 3.6 & - \\
\hline Passiflora alata & 5.0 & 2 & 7.3 & 11 & 5.8 & 10 & 4.8 & 0.4 \\
\hline Passiflora incarnata & 9.1 & 2 & 8.2 & $8-14$ & 5.1 & - & 1.1 & - \\
\hline Paulinia cupana & 0.8 & 3 & 7.8 & 9.5 & 2.1 & 3 & 1.4 & - \\
\hline Peumus boldus & 5.7 & 3 & 10.3 & 10 & 8.7 & 10 & 6.5 & 6 \\
\hline Phyllanihus niruri & 0.6 & 2 & 5.6 & 10 & 3.9 & 6 & 0.7 & - \\
\hline Pimpinella anisum & 0.7 & 2 & 7.6 & $8-14$ & 4.6 & 11 & 1.1 & - \\
\hline Plantago major & 7.9 & 2 & 9.0 & $8-14$ & 9.2 & - & 3.2 & - \\
\hline Polygonum punctatum & 0.05 & 2 & 6.8 & $8-14$ & 7.1 & - & 4.6 & - \\
\hline Psidium guajava & 45.2 & 2 & 7.4 & 12 & 4.0 & 9 & 0.6 & - \\
\hline Punica granatum & 1.2 & 2 & 9.1 & $8-14$ & 2.5 & - & 1.1 & - \\
\hline Rhamnus purshiana & 0.9 & 1 & 7.8 & 12 & 3.5 & 6 & 1.6 & 2 \\
\hline Rosmarinus officinales & 15.6 & 2 & 4.9 & $8-14$ & 3.9 & - & 0.5 & - \\
\hline Sálvia officinalis & 5.6 & 2 & 6.4 & $8-14$ & 12.1 & - & 6.4 & - \\
\hline Sambucus nigra & 26.5 & 8 & 7.0 & 11 & 6.8 & 9 & 1.6 & - \\
\hline Schinus terebinthifolia & 0.2 & 2 & 8.1 & $8-14$ & 5.9 & - & 0.1 & - \\
\hline
\end{tabular}


Table 2. Foreign matter quantities (FM), permitted foreign matter (PFM), moisture (M), permitted moisture, permitted moisture (PM) total ash (TA), permitted total ash (PTA) insoluble acid ash (IAA) and permitted insoluble acid ash (PIAA) (cont.)

\begin{tabular}{|c|c|c|c|c|c|c|c|c|}
\hline Scientific name & $\mathrm{FM} / \%$ & $\mathrm{PFM} / \%$ & $\mathrm{M} / \%$ & $\mathrm{PM} / \%$ & $\mathrm{TA} / \%$ & $\mathrm{PTA} / \%$ & IAA / \% & PIAA / \% \\
\hline Senna alexandrina & - & 2 & 6.2 & 10 & 10.8 & 12 & 2.6 & 3 \\
\hline Solanum paniculatum & 1.1 & 2 & 7.6 & $8-14$ & 6.8 & 14 & 2.0 & - \\
\hline Stryphnodendron adstringens & 0.06 & 2 & 6.8 & 14 & 0.5 & 2 & 0.2 & - \\
\hline Taraxacum officinale & 9.9 & 2 & 5.7 & $8-14$ & 13.1 & 10 & 7.2 & - \\
\hline Uncaria tomentosa & 2.4 & 2 & 8.2 & $8-14$ & 2.1 & - & 1.4 & - \\
\hline Vernonia polyanthes & 10.1 & 2 & 6.7 & $8-14$ & 6.0 & - & 3.1 & - \\
\hline Zingirber officinale & - & 2 & 7.5 & 10 & 2.9 & 6 & 2.3 & - \\
\hline
\end{tabular}

and the main foreign matter found was represented by parts of the plant other than what was indicated for use. Soil particles were, also, detected, but in small amounts. Moisture was found varying from 4 to $12 \%$ and only three samples showed values above the permitted levels: Allium sativum, Citrus auranrium and Illicium verum. However, it was noted that the majority of the samples had moisture contents close to the recommended. High moisture percentage may favor the appearance of mould, slime and plant deterioration. The amount limit of permitted ash was not found in the Brazilian Pharmacopeia, for all of the analyzed plants and among those which presented it, only four possess ash content higher than the limits: Arctium lappa, Cinnamomum verum, Illicium verum and Taraxacum officinalles. Just a few plants showed the permitted values for insoluble acid ash and only in Passiflora alata and Peumus boldus the measured values were higher.
The amount of ash is related to the physiological and non-physiological inorganic material content. The obtained inorganic ash indicates the presence of non-physiological inorganic material that can be related to inorganic waste contaminants.

The precision and accuracy of the method evaluated by analyzing certified reference material are shown in Table 3, for the results obtained by INAA, and in Table 4, for the results obtained by ICP OES and CV AAS for quality measurement and control purposes. It can be seen that the relative errors are generally less than $20 \%$, for most of the elements. Exceptions are $\mathrm{K}$ in peach leaves and $\mathrm{Co}$ in tomato leaves. Nevertheless, the general results were considered satisfactory regarding the low levels of concentrations normally observed in plant material. Cadmium concentrations in these reference materials was below the detection limit for ICP OES applied methodology $\left(0.06 \mathrm{mg} \mathrm{kg}^{-1}\right)$.

Table 3. Results obtained for the certificate reference materials apple, peach and tomato leaves, in $\mathrm{mg} \mathrm{kg}^{-1}$, excepted where indicated with \%, mean value $(\mathrm{n}=5)$, standard deviation and relative error

\begin{tabular}{|c|c|c|c|c|c|c|c|c|c|}
\hline & \multicolumn{3}{|c|}{ Apple leaves } & \multicolumn{3}{|c|}{ Peach leaves } & \multicolumn{3}{|c|}{ Tomato leaves } \\
\hline & $\begin{array}{c}\mathrm{MV} / \\
\left(\mathrm{mg} \mathrm{kg}^{-1}\right) \\
\end{array}$ & $\begin{array}{c}\mathrm{TV} / \\
\left(\mathrm{mg} \mathrm{kg}^{-1}\right) \\
\end{array}$ & $\begin{array}{c}\mathrm{RE} / \\
\left(\mathrm{mg} \mathrm{kg}^{-1}\right) \\
\end{array}$ & $\begin{array}{c}\mathrm{MV} / \\
\left(\mathrm{mg} \mathrm{kg}^{-1}\right) \\
\end{array}$ & $\begin{array}{c}\mathrm{TE} / \\
\left(\mathrm{mg} \mathrm{kg}^{-1}\right) \\
\end{array}$ & $\begin{array}{c}\mathrm{RE} / \\
\left(\mathrm{mg} \mathrm{kg}^{-1}\right) \\
\end{array}$ & $\begin{array}{c}\mathrm{MV} / \\
\left(\mathrm{mg} \mathrm{kg}^{-1}\right) \\
\end{array}$ & $\begin{array}{c}\mathrm{TV} / \\
\left(\mathrm{mg} \mathrm{kg}^{-1}\right) \\
\end{array}$ & $\begin{array}{c}\mathrm{RE} / \\
\left(\mathrm{mg} \mathrm{kg}^{-1}\right)\end{array}$ \\
\hline $\mathrm{Ba}$ & $51 \pm 11$ & $49 \pm 2$ & 4.8 & $118 \pm 26$ & $124 \pm 4$ & 4.6 & $49 \pm 10$ & 63 & 21.9 \\
\hline $\mathrm{Br}$ & & & & & & & $1489 \pm 193$ & 1300 & 14.6 \\
\hline $\mathrm{Ca} / \%$ & $1.20 \pm 0.40$ & $1.5 \pm 0.005$ & 20.0 & $1.2 \pm 0.2$ & $1.5 \pm 0.02$ & 20.0 & & & \\
\hline Co & & & & & & & $0.8 \pm 0.1$ & $0.57 \pm 0.02$ & 42.1 \\
\hline $\mathrm{Cr}$ & & & & & & & $1.9 \pm 0.3$ & $1.99 \pm 0.06$ & 2.8 \\
\hline $\mathrm{Fe}$ & $86 \pm 28$ & $83 \pm 5$ & 3.2 & $236 \pm 54$ & $218 \pm 14$ & 8.2 & $316 \pm 35$ & $368 \pm 7$ & 14.2 \\
\hline $\mathrm{Hf}$ & & & & & & & $0.16 \pm 0.04$ & 0.14 & 12.8 \\
\hline $\mathrm{K} / \%$ & $1.30 \pm 0.30$ & $1.61 \pm 0.02$ & 19.3 & $1.5 \pm 0.3$ & $2.43 \pm 0.03$ & 38.3 & $2.5 \pm 0.2$ & $2.7 \pm 0.05$ & 8.9 \\
\hline $\mathrm{Mg}$ & $2710 \pm 80$ & $2674 \pm 112$ & 1.3 & 1.3 & & & & & \\
\hline $\mathrm{Mn}$ & $54 \pm 3$ & $50 \pm 2$ & 6.5 & 7.4 & & & & & \\
\hline $\mathrm{Na}$ & $29 \pm 7$ & $24.4 \pm 1.2$ & 18.8 & $26 \pm 1$ & $24 \pm 2$ & 10.3 & $112 \pm 21$ & $136 \pm 4$ & 17.9 \\
\hline $\mathrm{Rb}$ & $10 \pm 3$ & $10.2 \pm 1.5$ & 0.3 & $19 \pm 7$ & $19.7 \pm 1.2$ & 6.0 & $12 \pm 2$ & $14.89 \pm 0.27$ & 18.6 \\
\hline $\mathrm{Sb}$ & & & & $0.024 \pm 0.002$ & 0.02 & 22.0 & & & \\
\hline $\mathrm{Sc}$ & $0.03 \pm 0.01$ & 0.03 & 11.2 & $0.05 \pm 0.01$ & 0.04 & 20.3 & $0.09 \pm 0.01$ & 0.1 & 5.8 \\
\hline V & $0.26 \pm 0.03$ & $0.23 \pm 0.06$ & 12 & 13 & & & & & \\
\hline $\mathrm{Zn}$ & $15 \pm 2$ & $12.5 \pm 0.3$ & 18.9 & $21 \pm 4$ & $17.9 \pm 0.4$ & 15.8 & $28 \pm 3$ & $30.9 \pm 0.7$ & 9.6 \\
\hline
\end{tabular}

$\mathrm{MV}$ : measured value; $\mathrm{TV}$ : true value; RE: relative error. 
Table 4. Results of the Certificate Reference Materials apple and peach leaves obtained by ICP OES and CV AAS, in mg kg-1 ${ }^{-1}$ mean value $(\mathrm{n}=5)$, standard deviation and relative error

\begin{tabular}{|c|c|c|c|c|c|c|}
\hline & \multicolumn{3}{|c|}{ Apple leaves } & \multicolumn{3}{|c|}{ Peach leaves } \\
\hline & $\mathrm{MV} /\left(\mathrm{mg} \mathrm{kg}^{-1}\right)$ & $\mathrm{TV} /\left(\mathrm{mg} \mathrm{kg}^{-1}\right)$ & $\mathrm{RE} /\left(\mathrm{mg} \mathrm{kg}^{-1}\right)$ & $\mathrm{MV} /\left(\mathrm{mg} \mathrm{kg}^{-1}\right)$ & $\mathrm{TV} /\left(\mathrm{mg} \mathrm{kg}^{-1}\right)$ & $\mathrm{RE} /\left(\mathrm{mg} \mathrm{kg}^{-1}\right)$ \\
\hline $\mathrm{Cd}$ & - & $0.013 \pm 2$ & - & - & $0.026 \pm 0.003$ & - \\
\hline $\mathrm{Cu}$ & $5 \pm 1$ & $5.64 \pm 0.24$ & 11.3 & $3.77 \pm 0.07$ & $3.7 \pm 0.4$ & 1.9 \\
\hline $\mathrm{Ni}$ & $0.9 \pm 0.2$ & $0.91 \pm 0.12$ & 1.1 & $0.56 \pm 0.02$ & $0.69 \pm 0.09$ & 18.8 \\
\hline $\mathrm{Pb}$ & $0.55 \pm 0.08$ & $0.47 \pm 0.024$ & 17 & $0.7 \pm 0.3$ & $0.87 \pm 0.03$ & 19.5 \\
\hline $\mathrm{Hg}$ & $39 \pm 4$ & $44 \pm 4$ & 11.4 & $36 \pm 9$ & $36 \pm 9$ & 16 \\
\hline
\end{tabular}

MV: measured value; TV: true value; RE: relative error.

The results obtained for the element concentrations in the samples, all in dry basis, are shown in Table 5. Blanks in Table 5 mean values below the limit of detection (LOD), presented by Francisconi. ${ }^{18}$

It can be noted, from the data in Table 5 that the concentration in the medicinal plant samples varies in a wide range for almost all the elements. The main reason for this variation certainly must be the fact that different species and different plant parts were analyzed. Furthermore, water sources, climatic conditions and environmental pollution must also contribute for the variation. ${ }^{20}$

\section{Discussion}

Good quality control of medicinal plants is important, since they are normally consumed without any limitation. It is almost a consensus that, being a natural product, they do not pose any harm to health. Concerning the element concentrations present in medicinal plants, besides the essential elements, they also may contain toxic and non-toxic elements, but, in concentrations above the permissible levels.

In fact, among the elements determined in this paper, only $\mathrm{As}, \mathrm{Cd}$ and $\mathrm{Pb}$ has been limited by $\mathrm{WHO}^{14}$ in plants

Table 5. Concentrations and expanded uncertainty $(K=2)$ obtained in the analyzed samples

\begin{tabular}{|c|c|c|c|c|c|c|}
\hline Scientific name & As / $\left(\mathrm{mg} \mathrm{kg}^{-1}\right)$ & $\mathrm{Cl} / \%$ & $\mathrm{Cs} /\left(\mathrm{mg} \mathrm{kg}^{-1}\right)$ & $\mathrm{Hf} /\left(\mathrm{mg} \mathrm{kg}^{-1}\right)$ & $\mathrm{K} / \%$ & $\mathrm{Mg} / \%$ \\
\hline A. millefolium & & $0.56 \pm 0.02$ & $0.034 \pm 0.004$ & $0.048 \pm 0.003$ & $2.1 \pm 0.6$ & $0.19 \pm 0.03$ \\
\hline A. satureioides & & $0.52 \pm 0.02$ & $0.24 \pm 0.01$ & $0.63 \pm 0.01$ & $0.9 \pm 0.2$ & $0.25 \pm 0.01$ \\
\hline A. hippocastanum & & $0.56 \pm 0.03$ & $0.06 \pm 0.01$ & $0.72 \pm 0.02$ & $0.032 \pm 0.002$ & $0.069 \pm 0.007$ \\
\hline A. conyzoides & & $0.28 \pm 0.01$ & $0.20 \pm 0.02$ & $2.29 \pm 0.07$ & $1.9 \pm 0.4$ & $1.14 \pm 0.04$ \\
\hline A. sativum & & & & $0.034 \pm 0.008$ & & $0.012 \pm 0.008$ \\
\hline A. occidentales & & $0.78 \pm 0.06$ & $0.026 \pm 0.003$ & $0.118 \pm 0.004$ & $0.30 \pm 0.08$ & $0.060 \pm 0.005$ \\
\hline A. lappa & & $0.5 \pm 0.2$ & $0.081 \pm 0.006$ & $0.062 \pm 0.003$ & $6.4 \pm 0.7$ & $0.034 \pm 0.008$ \\
\hline A. montana & & $0.08 \pm 0.01$ & $0.14 \pm 0.02$ & $0.056 \pm 0.007$ & $3.0 \pm 0.5$ & $0.11 \pm 0.02$ \\
\hline B. trimera & & & $0.28 \pm 0.02$ & $0.11 \pm 0.01$ & $2.4 \pm 0.6$ & $0.17 \pm 0.02$ \\
\hline B. pilosa & & $0.24 \pm 0.02$ & $0.08 \pm 0.01$ & $0.141 \pm 0.005$ & $4.0 \pm 0.3$ & $0.28 \pm 0.02$ \\
\hline C. ferrea & & $0.32 \pm 0.01$ & & & $0.7 \pm 0.2$ & $0.073 \pm 0.007$ \\
\hline C. officinalis & & $0.59 \pm 0.02$ & $0.11 \pm 0.01$ & & $3.2 \pm 0.3$ & $0.36 \pm 0.02$ \\
\hline C. sylvestris & & & $2.0 \pm 0.1$ & $0.054 \pm 0.006$ & $1.3 \pm 0.2$ & $0.18 \pm 0.02$ \\
\hline C. verum & & $0.59 \pm 0.02$ & & $0.014 \pm 0.003$ & $0.7 \pm 0.1$ & $0.024 \pm 0.005$ \\
\hline C. auranrium & & $0.62 \pm 0.02$ & $0.051 \pm 0.006$ & & $0.7 \pm 0.1$ & $0.070 \pm 0.004$ \\
\hline C. verbanacea & & $0.70 \pm 0.04$ & $0.112 \pm 0.007$ & $0.056 \pm 0.003$ & $0.8 \pm 0.1$ & $0.22 \pm 0.02$ \\
\hline C. longa & & $0.32 \pm 0.01$ & $0.10 \pm 0.01$ & $0.042 \pm 0.003$ & $1.99 \pm 0.04$ & $0.12 \pm 0.01$ \\
\hline C. citratus & & $0.25 \pm 0.02$ & $0.183 \pm 0.009$ & $0.042 \pm 0.003$ & $3.3 \pm 0.7$ & $0.14 \pm 0.01$ \\
\hline C. scolymus & & & & $0.119 \pm 0.008$ & $8 \pm 2$ & $0.29 \pm 0.01$ \\
\hline E. macrophyllus & & $1.32 \pm 0.04$ & $0.15 \pm 0.01$ & $0.074 \pm 0.008$ & $4.9 \pm 0.8$ & $0.17 \pm 0.02$ \\
\hline E. arvense & & $1.9 \pm 0.1$ & $4.3 \pm 0.2$ & $0.04 \pm 0.01$ & $3 \pm 1$ & \\
\hline E. verna & $0.06 \pm 0.01$ & $0.43 \pm 0.02$ & $0.15 \pm 0.01$ & $0.111 \pm 0.005$ & $2.7 \pm 0.6$ & $0.12 \pm 0.01$ \\
\hline E. globulus & & $0.17 \pm 0.01$ & & $0.107 \pm 0.008$ & $0.29 \pm 0.08$ & \\
\hline E. uniflora & & $0.12 \pm 0.02$ & $0.065 \pm 0.008$ & $0.054 \pm 0.005$ & $1.5 \pm 0.4$ & $0.17 \pm 0.03$ \\
\hline G. glaba & & $0.14 \pm 0.01$ & $0.035 \pm 0.003$ & $0.025 \pm 0.001$ & $0.26 \pm 0.05$ & $0.10 \pm 0.01$ \\
\hline H. virginiana & & $1.3 \pm 0.1$ & $0.03 \pm 0.01$ & & $1.0 \pm 0.2$ & $0.13 \pm 0.01$ \\
\hline H. procumbens & & $0.63 \pm 0.03$ & $0.12 \pm 0.01$ & $0.76 \pm 0.02$ & $1.4 \pm 0.3$ & $0.11 \pm 0.03$ \\
\hline
\end{tabular}


Table 5. Concentrations and expanded uncertainty $(\mathrm{K}=2)$ obtained in the analyzed samples (cont.)

\begin{tabular}{|c|c|c|c|c|c|c|c|}
\hline Scientific name & $\mathrm{As} /\left(\mathrm{mg} \mathrm{kg}^{-1}\right)$ & $\mathrm{Cl} / \%$ & $\mathrm{Cs} /\left(\mathrm{mg} \mathrm{kg}^{-1}\right)$ & $\mathrm{Hf} /\left(\mathrm{mg} \mathrm{kg}^{-1}\right)$ & $\mathrm{K} / \%$ & $\mathrm{Mg} / \%$ & \\
\hline I. verum & & $0.91 \pm 0.08$ & $1.15 \pm 0.08$ & $0.050 \pm 0.008$ & $1.6 \pm 0.3$ & $0.063 \pm 0.007$ & \\
\hline L. sidoides & $0.31 \pm 0.02$ & $0.11 \pm 0.01$ & & & $0.7 \pm 0.1$ & $0.301 \pm 0.01$ & \\
\hline M. sylvestris & & $0.24 \pm 0.01$ & $0.17 \pm 0.02$ & $1.69 \pm 0.04$ & $3.3 \pm 0.5$ & $0.51 \pm 0.03$ & \\
\hline M. recutita & & & & $0.093 \pm 0.006$ & $3.8 \pm 0.6$ & $0.21 \pm 0.01$ & \\
\hline M. ilicifolia & & $0.04 \pm 0.01$ & $0.029 \pm 0.008$ & $0.042 \pm 0.004$ & $3.4 \pm 0.5$ & $0.68 \pm 0.04$ & \\
\hline M. officinales & & $1.60 \pm 0.06$ & $0.12 \pm 0.01$ & $0.067 \pm 0.006$ & $2.1 \pm 0.3$ & $0.37 \pm 0.01$ & \\
\hline M. piperita & & $0.32 \pm 0.01$ & & $0.26 \pm 0.01$ & $0.63 \pm 0.08$ & $0.70 \pm 0.05$ & \\
\hline M. pulegium & & & $0.35 \pm 0.04$ & $2.34 \pm 0.05$ & $1.99 \pm 0.04$ & $0.22 \pm 0.02$ & \\
\hline M. glomerata & & $0.072 \pm 0.004$ & $0.46 \pm 0.02$ & $0.055 \pm 0.002$ & $0.5 \pm 0.2$ & $0.11 \pm 0.02$ & \\
\hline M. charantia & & $0.29 \pm 0.01$ & $0.21 \pm 0.02$ & $0.080 \pm 0.006$ & $6 \pm 4$ & $0.40 \pm 0.02$ & \\
\hline P. alata & & $0.73 \pm 0.05$ & & $0.065 \pm 0.003$ & $3.6 \pm 0.9$ & $0.32 \pm 0.01$ & \\
\hline P. incarnata & & $0.87 \pm 0.03$ & $0.96 \pm 0.06$ & $0.38 \pm 0.01$ & $1.2 \pm 0.3$ & $0.20 \pm 0.04$ & \\
\hline P. cupana & $0.12 \pm 0.01$ & & $0.13 \pm 0.01$ & $0.024 \pm 0.002$ & $0.62 \pm 0.08$ & $0.113 \pm 0.005$ & \\
\hline P. boldus & & $0.029 \pm 0.003$ & $0.13 \pm 0.01$ & $0.058 \pm 0.003$ & $1.00 \pm 0.02$ & $0.18 \pm 0.01$ & \\
\hline P. niruri & $0.3 \pm 0.05$ & $1.06 \pm 0.05$ & & $0.227 \pm 0.007$ & & $0.29 \pm 0.03$ & \\
\hline P. onisum & & $1.0 \pm 0.2$ & $0.039 \pm 0.004$ & $0.059 \pm 0.003$ & $2.6 \pm 0.4$ & $0.189 \pm 0.008$ & \\
\hline P. major & & $0.025 \pm 0.003$ & $0.19 \pm 0.03$ & $0.18 \pm 0.01$ & $3.4 \pm 0.9$ & $0.75 \pm 0.03$ & \\
\hline P. punctatum & & $0.48 \pm 0.02$ & $0.23 \pm 0.02$ & & $2.0 \pm 0.4$ & $0.65 \pm 0.02$ & \\
\hline P. guajava & $0.05 \pm 0.02$ & $0.17 \pm 0.01$ & $0.047 \pm 0.007$ & $0.051 \pm 0.005$ & $0.011 \pm 0.001$ & $0.21 \pm 0.02$ & \\
\hline P. granatum & $0.17 \pm 0.03$ & $0.045 \pm 0.002$ & $0.071 \pm 0.008$ & $0.046 \pm 0.004$ & $4 \pm 1$ & $0.03 \pm 0.01$ & \\
\hline R. purshiana & & $0.031 \pm 0.003$ & $0.036 \pm 0.007$ & $0.025 \pm 0.003$ & $0.7 \pm 0.1$ & $0.26 \pm 0.02$ & \\
\hline R. officinales & $0.25 \pm 0.04$ & $0.24 \pm 0.04$ & $0.08 \pm 0.01$ & $0.063 \pm 0.006$ & $2.1 \pm 0.5$ & $0.24 \pm 0.01$ & \\
\hline S. officinalis & & $0.017 \pm 0.002$ & $0.32 \pm 0.04$ & $2.625 \pm 0.081$ & $1.9 \pm 0.3$ & $0.43 \pm 0.02$ & \\
\hline S. nigra & & $0.18 \pm 0.01$ & $0.027 \pm 0.008$ & $0.042 \pm 0.005$ & $3.0 \pm 0.2$ & $0.32 \pm 0.01$ & \\
\hline S. terebinthifolia & & $0.016 \pm 0.003$ & & $0.069 \pm 0.006$ & $0.5 \pm 0.1$ & $0.26 \pm 0.01$ & \\
\hline S. alexandrina & $0.07 \pm 0.02$ & $0.39 \pm 0.02$ & $0.076 \pm 0.01$ & $0.228 \pm 0.014$ & $0.9 \pm 0.2$ & $0.46 \pm 0.02$ & \\
\hline S. paniculatum & & $0.02 \pm 0.002$ & $0.22 \pm 0.03$ & $1.447 \pm 0.045$ & $1.7 \pm 0.2$ & $0.22 \pm 0.02$ & \\
\hline St. adstringens & & $1.38 \pm 0.06$ & $0.022 \pm 0.009$ & $0.092 \pm 0.004$ & $0.8 \pm 0.2$ & $0.028 \pm 0.006$ & \\
\hline T. officinalles & $0.59 \pm 0.08$ & $0.48 \pm 0.04$ & $0.48 \pm 0.06$ & $0.792 \pm 0.027$ & $5 \pm 3$ & $0.29 \pm 0.02$ & \\
\hline U. tomentosa & & & & $0.016 \pm 0.006$ & $0.09 \pm 0.02$ & $0.199 \pm 0.008$ & \\
\hline V. polyanthes & & $0.58 \pm 0.02$ & $0.15 \pm 0.03$ & & $1.8 \pm 0.4$ & $0.22 \pm 0.02$ & \\
\hline Z. officinale & $0.53 \pm 0.05$ & $0.12 \pm 0.01$ & $0.014 \pm 0.007$ & $0.027 \pm 0.003$ & $2 \pm 1$ & $0.14 \pm 0.01$ & \\
\hline Scientific name & $\mathrm{Sb} /\left(\mathrm{mg} \mathrm{kg}^{-1}\right)$ & $\mathrm{Sc} /\left(\mathrm{mg} \mathrm{kg}^{-1}\right)$ & $\mathrm{Cd} /\left(\mathrm{mg} \mathrm{kg}^{-1}\right)$ & $\mathrm{Co} /\left(\mathrm{mg} \mathrm{kg}^{-1}\right)$ & $\mathrm{Cr} /\left(\mathrm{mg} \mathrm{kg}^{-1}\right)$ & $\mathrm{Cu} /\left(\mathrm{mg} \mathrm{kg}^{-1}\right)$ & $\mathrm{Br} /\left(\mathrm{mg} \mathrm{kg}^{-1}\right)$ \\
\hline A. millefolium & $0.021 \pm 0.004$ & $0.018 \pm 0.001$ & $0.25 \pm 0.04$ & $0.18 \pm 0.02$ & $5.1 \pm 0.4$ & $12.71 \pm 0.08$ & $15.4 \pm 0.2$ \\
\hline A. satureioides & $0.027 \pm 0.005$ & $0.132 \pm 0.003$ & $0.08 \pm 0.05$ & $0.40 \pm 0.02$ & $30 \pm 2$ & $9.67 \pm 0.06$ & $11.1 \pm 0.1$ \\
\hline A. hippocastanum & & $0.023 \pm 0.001$ & & $1.76 \pm 0.08$ & $257 \pm 20$ & $9.2 \pm 0.3$ & $115.3 \pm 0.6$ \\
\hline A. conyzoides & $0.05 \pm 0.01$ & $0.67 \pm 0.02$ & $0.12 \pm 0.03$ & $1.56 \pm 0.09$ & $23 \pm 1$ & $5.0 \pm 0.2$ & $109.3 \pm 0.6$ \\
\hline A. sativum & & $0.001 \pm 0.001$ & $0.07 \pm 0.03$ & $0.14 \pm 0.01$ & $0.7 \pm 0.2$ & $3.9 \pm 0.1$ & $1.16 \pm 0.06$ \\
\hline A. occidentales & $0.013 \pm 0.003$ & $0.0021 \pm 0.0001$ & & $0.22 \pm 0.01$ & $18 \pm 1$ & $3.5 \pm 0.1$ & $1.99 \pm 0.03$ \\
\hline A. lappa & $0.049 \pm 0.009$ & $0.038 \pm 0.001$ & & $0.44 \pm 0.03$ & $34 \pm 2$ & $10.7 \pm 0.2$ & $29.7 \pm 0.2$ \\
\hline A. montana & & $0.062 \pm 0.002$ & $0.51 \pm 0.07$ & $0.40 \pm 0.04$ & $13.9 \pm 0.9$ & $8.8 \pm 0.2$ & $45.6 \pm 0.4$ \\
\hline B. trimera & $0.037 \pm 0.007$ & $0.066 \pm 0.002$ & $0.20 \pm 0.03$ & $0.60 \pm 0.04$ & $7.8 \pm 0.4$ & $10.09 \pm 0.5$ & $8.97 \pm 0.1$ \\
\hline B. pilosa & & $0.074 \pm 0.002$ & $0.24 \pm 0.03$ & $0.38 \pm 0.02$ & $6.3 \pm 0.5$ & $13.4 \pm 0.2$ & $41.6 \pm 0.2$ \\
\hline C. ferrea & & & & $0.19 \pm 0.02$ & $1.1 \pm 0.1$ & $2.65 \pm 0.04$ & $18.9 \pm 0.3$ \\
\hline C. officinalis & $0.005 \pm 0.002$ & $0.024 \pm 0.001$ & $0.16 \pm 0.05$ & $0.25 \pm 0.01$ & $4.6 \pm 0.2$ & $8.30 \pm 0.06$ & $21.1 \pm 0.1$ \\
\hline C. sylvestris & $0.081 \pm 0.008$ & $0.048 \pm 0.001$ & $0.10 \pm 0.04$ & $0.24 \pm 0.01$ & $4.6 \pm 0.2$ & $8.3 \pm 0.2$ & $40.2 \pm 1.3$ \\
\hline C. verum & & $0.0031 \pm 0.0003$ & $0.22 \pm 0.01$ & $0.14 \pm 0.01$ & $6.7 \pm 0.4$ & $3.11 \pm 0.09$ & $40.5 \pm 0.2$ \\
\hline C. auranrium & $0.005 \pm 0.001$ & $0.0076 \pm 0.0005$ & & $0.19 \pm 0.01$ & $13.4 \pm 0.8$ & $3.5 \pm 0.1$ & $1.66 \pm 0.02$ \\
\hline C. verbanacea & & $0.067 \pm 0.002$ & & $0.95 \pm 0.06$ & $20.5 \pm 0.9$ & $13.8 \pm 0.1$ & $27.6 \pm 0.2$ \\
\hline C. longa & & $0.105 \pm 0.003$ & $0.04 \pm 0.02$ & $0.19 \pm 0.01$ & $1.00 \pm 0.07$ & $7.14 \pm 0.08$ & $26.1 \pm 0.2$ \\
\hline C. citratus & & $0.0145 \pm 0.0004$ & $0.07 \pm 0.05$ & $0.35 \pm 0.02$ & $14.4 \pm 0.9$ & $6.4 \pm 0.2$ & $74 \pm 0.4$ \\
\hline C. scolymus & & $0.126 \pm 0.002$ & & $0.58 \pm 0.02$ & $31 \pm 1$ & $5.52 \pm 0.01$ & $33 \pm 1$ \\
\hline E. macrophyllus & & $0.101 \pm 0.003$ & $0.07 \pm 0.03$ & $0.98 \pm 0.06$ & $32 \pm 2$ & $7.4 \pm 0.2$ & $168 \pm 1$ \\
\hline
\end{tabular}


Table 5. Concentrations and expanded uncertainty $(K=2)$ obtained in the analyzed samples (cont.)

\begin{tabular}{|c|c|c|c|c|c|c|c|}
\hline Scientific name & $\mathrm{Sb} /\left(\mathrm{mg} \mathrm{kg}^{-1}\right)$ & $\mathrm{Sc} /\left(\mathrm{mg} \mathrm{kg}^{-1}\right)$ & $\mathrm{Cd} /\left(\mathrm{mg} \mathrm{kg}^{-1}\right)$ & $\mathrm{Co} /\left(\mathrm{mg} \mathrm{kg}^{-1}\right)$ & $\mathrm{Cr} /\left(\mathrm{mg} \mathrm{kg}^{-1}\right)$ & $\mathrm{Cu} /\left(\mathrm{mg} \mathrm{kg}^{-1}\right)$ & $\mathrm{Br} /\left(\mathrm{mg} \mathrm{kg}^{-1}\right)$ \\
\hline E. arvense & $0.090 \pm 0.006$ & $0.007 \pm 0.001$ & & $0.62 \pm 0.04$ & $6.2 \pm 0.4$ & $7.71 \pm 0.01$ & $142 \pm 1$ \\
\hline E. verna & $0.039 \pm 0.004$ & $0.063 \pm 0.002$ & & $0.41 \pm 0.03$ & $14.8 \pm 0.9$ & $2.70 \pm 0.04$ & $8.74 \pm 0.05$ \\
\hline E. globulus & $0.040 \pm 0.007$ & $0.16 \pm 0.003$ & $0.04 \pm 0.03$ & $0.38 \pm 0.02$ & $2.9 \pm 0.1$ & $9.1 \pm 0.1$ & $15.2 \pm 0.2$ \\
\hline E. uniflora & $0.037 \pm 0.006$ & $0.04 \pm 0.001$ & $0.03 \pm 0.01$ & $3.7 \pm 0.1$ & $2.3 \pm 0.1$ & $8.9 \pm 0.1$ & $3.22 \pm 0.09$ \\
\hline G. glaba & $0.010 \pm 0.004$ & $0.019 \pm 0.001$ & & $0.29 \pm 0.02$ & $24 \pm 1$ & $3.39 \pm 0.05$ & $4.79 \pm 0.06$ \\
\hline H. virginiana & & $0.017 \pm 0.001$ & & $0.24 \pm 0.02$ & $16 \pm 2$ & $4.23 \pm 0.07$ & $11.9 \pm 0.2$ \\
\hline H. procumbens & $0.034 \pm 0.008$ & $0.26 \pm 0.009$ & & $0.51 \pm 0.03$ & $11.7 \pm 0.9$ & $6.11 \pm 0.07$ & $45.4 \pm 0.2$ \\
\hline I. verum & & $0.045 \pm 0.002$ & $0.04 \pm 0.02$ & $0.27 \pm 0.03$ & $12.4 \pm 0.9$ & $8.6 \pm 0.1$ & $0.72 \pm 0.01$ \\
\hline L. sidoides & & $0.0081 \pm 0.0002$ & & $0.21 \pm 0.02$ & $4.5 \pm 0.4$ & $6.82 \pm 0.03$ & $11.94 \pm 0.06$ \\
\hline M. sylvestris & $0.02 \pm 0.01$ & $0.343 \pm 0.008$ & $0.05 \pm 0.04$ & $0.91 \pm 0.04$ & $52 \pm 3$ & $8.16 \pm 0.08$ & $67.2 \pm 0.2$ \\
\hline M. recutita & & $0.047 \pm 0.001$ & $0.04 \pm 0.02$ & $0.79 \pm 0.04$ & $68 \pm 5$ & $9.1 \pm 0.2$ & $34.1 \pm 0.2$ \\
\hline M. ilicifolia & & $0.026 \pm 0.001$ & $0.06 \pm 0.04$ & $0.16 \pm 0.01$ & $1.01 \pm 0.09$ & $5.89 \pm 0.09$ & $6.10 \pm 0.07$ \\
\hline M. officinales & $0.025 \pm 0.005$ & $0.041 \pm 0.001$ & $0.06 \pm 0.05$ & $0.30 \pm 0.02$ & $8.1 \pm 0.5$ & $14.8 \pm 0.3$ & $7.69 \pm 0.05$ \\
\hline M. piperita & $0.020 \pm 0.009$ & $0.59 \pm 0.02$ & $0.04 \pm 0.02$ & $0.94 \pm 0.06$ & $4.5 \pm 0.2$ & $11.9 \pm 0.2$ & $26.0 \pm 0.2$ \\
\hline M. pulegium & $0.052 \pm 0.006$ & $3.66 \pm 0.09$ & $0.07 \pm 0.01$ & $9.12 \pm 0.47$ & $69 \pm 3$ & $10.7 \pm 0.1$ & $43.2 \pm 0.2$ \\
\hline M. glomerata & $0.023 \pm 0.004$ & $0.029 \pm 0.001$ & $0.20 \pm 0.08$ & $0.21 \pm 0.01$ & $10.7 \pm 0.5$ & $10.9 \pm 0.2$ & $9.7 \pm 0.1$ \\
\hline M. charantia & $0.034 \pm 0.007$ & $0.064 \pm 0.002$ & & $2.49 \pm 0.21$ & $133 \pm 7$ & $9.3 \pm 0.2$ & $17.8 \pm 0.2$ \\
\hline P. alata & $0.010 \pm 0.002$ & $0.039 \pm 0.001$ & & $0.07 \pm 0.01$ & $2.6 \pm 0.1$ & $7.3 \pm 0.2$ & $6.59 \pm 0.05$ \\
\hline P. incarnata & $0.077 \pm 0.014$ & $0.220 \pm 0.004$ & & $0.66 \pm 0.03$ & $47.8 \pm 1$ & $7.0 \pm 0.1$ & $89 \pm 3$ \\
\hline P. cupana & $0.009 \pm 0.002$ & $0.0139 \pm 0.0004$ & & $0.38 \pm 0.02$ & $0.5 \pm 0.03$ & $16.5 \pm 0.2$ & $6.01 \pm 0.05$ \\
\hline P. boldus & & $0.080 \pm 0.002$ & & $0.29 \pm 0.01$ & $18.1 \pm 0.8$ & $2.0 \pm 0.1$ & $18.6 \pm 0.1$ \\
\hline P. niruri & $0.022 \pm 0.004$ & $0.59 \pm 0.01$ & $0.46 \pm 0.05$ & $0.65 \pm 0.02$ & $6.1 \pm 0.2$ & $7.9 \pm 0.2$ & $10.4 \pm 0.3$ \\
\hline P. onisum & $0.013 \pm 0.005$ & $0.032 \pm 0.001$ & & $0.45 \pm 0.03$ & $34 \pm 2$ & $11.66 \pm 0.03$ & $24.1 \pm 0.2$ \\
\hline P. major & $0.011 \pm 0.005$ & $2.03 \pm 0.06$ & & $3.81 \pm 0.23$ & $12.2 \pm 0.7$ & $15.9 \pm 0.2$ & $36.7 \pm 0.2$ \\
\hline P. punctatum & $0.020 \pm 0.008$ & $0.065 \pm 0.002$ & $0.04 \pm 0.01$ & $0.57 \pm 0.04$ & $36 \pm 2$ & $11.7 \pm 0.1$ & $17.5 \pm 0.2$ \\
\hline P. guajava & $0.024 \pm 0.004$ & $0.030 \pm 0.001$ & & $0.25 \pm 0.01$ & $1.7 \pm 0.1$ & $13.88 \pm 0.04$ & $4.78 \pm 0.07$ \\
\hline P. granatum & & $0.017 \pm 0.001$ & & $0.11 \pm 0.02$ & $1.08 \pm 0.09$ & $4.75 \pm 0.05$ & $63.5 \pm 0.4$ \\
\hline R. purshiana & & $0.013 \pm 0.001$ & & $0.09 \pm 0.01$ & $1.3 \pm 0.1$ & $1.88 \pm 0.07$ & $66.9 \pm 0.4$ \\
\hline R. officinales & & $0.097 \pm 0.002$ & & $0.31 \pm 0.01$ & $4.6 \pm 0.2$ & $4.57 \pm 0.01$ & $13.6 \pm 0.1$ \\
\hline S. officinalis & $0.04 \pm 0.01$ & $0.91 \pm 0.03$ & $0.10 \pm 0.04$ & $0.91 \pm 0.06$ & $52 \pm 3$ & $24.5 \pm 0.2$ & $17.7 \pm 0.3$ \\
\hline S. nigra & $0.040 \pm 0.006$ & $0.059 \pm 0.001$ & $0.06 \pm 0.03$ & $0.25 \pm 0.01$ & $11.2 \pm 0.5$ & $11.2 \pm 0.1$ & $7.1 \pm 0.1$ \\
\hline S. terebinthifolia & & $0.007 \pm 0.001$ & & $0.15 \pm 0.01$ & $3.2 \pm 0.2$ & $3.57 \pm 0.08$ & $5.5 \pm 0.1$ \\
\hline S. alexandrina & $0.006 \pm 0.003$ & $0.147 \pm 0.005$ & & $0.38 \pm 0.02$ & $30 \pm 1$ & $4.92 \pm 0.04$ & $30.5 \pm 0.1$ \\
\hline S. paniculatum & $0.023 \pm 0.004$ & $0.105 \pm 0.002$ & & $0.76 \pm 0.02$ & $36 \pm 1$ & $14.68 \pm 0.07$ & $80 \pm 3$ \\
\hline St. adstringens & $0.030 \pm 0.005$ & $0.003 \pm 0.0003$ & & $0.19 \pm 0.02$ & $6.5 \pm 0.3$ & $5.9 \pm 0.2$ & $7.75 \pm 0.1$ \\
\hline T. officinalles & $0.035 \pm 0.007$ & $0.58 \pm 0.02$ & $0.06 \pm 0.03$ & $1.22 \pm 0.08$ & $9.6 \pm 0.7$ & $7.04 \pm 0.06$ & $128 \pm 1$ \\
\hline U. tomentosa & & $0.049 \pm 0.002$ & & $0.12 \pm 0.01$ & $0.8 \pm 0.1$ & $7.1 \pm 0.1$ & $1.66 \pm 0.09$ \\
\hline V. polyanthes & $0.030 \pm 0.009$ & $0.101 \pm 0.004$ & $0.55 \pm 0.08$ & $0.31 \pm 0.02$ & $11.0 \pm 0.8$ & $11.0 \pm 0.2$ & $2.6 \pm 0.1$ \\
\hline Z. officinale & $0.010 \pm 0.002$ & $0.016 \pm 0.001$ & $0.26 \pm 0.01$ & $0.60 \pm 0.03$ & $16.0 \pm 0.8$ & $3.93 \pm 0.02$ & $2.82 \pm 0.04$ \\
\hline Scientific name & $\mathrm{Ca} / \%$ & $\mathrm{Fe} /\left(\mathrm{mg} \mathrm{kg}^{-1}\right)$ & $\mathrm{Hg} /\left(\mu \mathrm{g} \mathrm{kg}^{-1}\right)$ & $\mathrm{Ni} /\left(\mathrm{mg} \mathrm{kg}^{-1}\right)$ & $\mathrm{Mn} /\left(\mathrm{mg} \mathrm{kg}^{-1}\right)$ & $\mathrm{Na} /\left(\mathrm{mg} \mathrm{kg}^{-1}\right)$ & $\mathrm{Ba} /\left(\mathrm{mg} \mathrm{kg}^{-1}\right)$ \\
\hline A. millefolium & $1.1 \pm 0.2$ & $93 \pm 1$ & $101 \pm 3$ & $10.7 \pm 0.6$ & $128 \pm 7$ & $104 \pm 3$ & $19.9 \pm 0.9$ \\
\hline A. satureioides & $0.33 \pm 0.04$ & $429 \pm 5$ & $40 \pm 3$ & $6.7 \pm 0.2$ & $73 \pm 2$ & $270 \pm 7$ & $68 \pm 3$ \\
\hline A. hippocastanum & $0.22 \pm 0.04$ & $1215 \pm 13$ & $2.5 \pm 0.5$ & $27.0 \pm 0.4$ & $126 \pm 3$ & $113 \pm 5$ & \\
\hline A. conyzoides & $2.2 \pm 0.3$ & $2189 \pm 23$ & $24 \pm 2$ & $0.8 \pm 0.1$ & $239 \pm 6$ & $1633 \pm 38$ & $121 \pm 7$ \\
\hline A. sativum & $0.03 \pm 0.01$ & $26 \pm 4$ & $13 \pm 5$ & $0.4 \pm 0.2$ & $6.9 \pm 0.5$ & $489 \pm 17$ & \\
\hline A. occidentales & $1.8 \pm 0.7$ & $236 \pm 3$ & $8 \pm 2$ & $6.1 \pm 0.1$ & $94 \pm 4$ & $87 \pm 2$ & $96 \pm 5$ \\
\hline A. lappa & $1.3 \pm 0.2$ & $177 \pm 2$ & $42 \pm 1$ & $9.2 \pm 0.5$ & $17.1 \pm 0.7$ & $82 \pm 2$ & $33 \pm 2$ \\
\hline A. montana & $1.0 \pm 0.1$ & $285 \pm 6$ & $52 \pm 4$ & $2.9 \pm 0.1$ & $733 \pm 274$ & $162 \pm 5$ & $48 \pm 3$ \\
\hline B. trimera & $0.61 \pm 0.06$ & $283 \pm 4$ & $52 \pm 1$ & $4.3 \pm 0.3$ & $424 \pm 10$ & $738 \pm 17$ & $81 \pm 5$ \\
\hline B. pilosa & $0.87 \pm 0.13$ & $317 \pm 4$ & $32 \pm 6$ & $2.4 \pm 0.2$ & $102 \pm 2$ & $76 \pm 3$ & $141 \pm 6$ \\
\hline C. ferrea & $2.4 \pm 0.3$ & & $20 \pm 9$ & $0.7 \pm 0.3$ & $67 \pm 2$ & & $101 \pm 5$ \\
\hline C. officinalis & $0.47 \pm 0.06$ & $175 \pm 4$ & $3 \pm 2$ & $1.2 \pm 0.2$ & $150 \pm 4$ & $793 \pm 19$ & $20 \pm 2$ \\
\hline C. sylvestris & $0.43 \pm 0.05$ & $134 \pm 4$ & $63 \pm 3$ & $3.9 \pm 0.2$ & $716 \pm 15$ & $8 \pm 1$ & $47 \pm 2$ \\
\hline C. verum & $1.4 \pm 0.1$ & $55 \pm 3$ & $104 \pm 6$ & $2.4 \pm 0.3$ & $565 \pm 213$ & $9 \pm 1$ & $2 \pm 1$ \\
\hline
\end{tabular}


Table 5. Concentrations and expanded uncertainty $(K=2)$ obtained in the analyzed samples (cont.)

\begin{tabular}{|c|c|c|c|c|c|c|c|}
\hline Scientific name & $\mathrm{Ca} / \%$ & $\mathrm{Fe} /\left(\mathrm{mg} \mathrm{kg}^{-1}\right)$ & $\mathrm{Hg} /\left(\mu \mathrm{g} \mathrm{kg}^{-1}\right)$ & $\mathrm{Ni} /\left(\mathrm{mg} \mathrm{kg}^{-1}\right)$ & $\mathrm{Mn} /\left(\mathrm{mg} \mathrm{kg}^{-1}\right)$ & $\mathrm{Na} /\left(\mathrm{mg} \mathrm{kg}^{-1}\right)$ & $\mathrm{Ba} /\left(\mathrm{mg} \mathrm{kg}^{-1}\right)$ \\
\hline C. auranrium & $0.48 \pm 0.05$ & $88 \pm 3$ & $44 \pm 3$ & $5.1 \pm 0.3$ & $6.1 \pm 0.3$ & $374 \pm 9$ & $53 \pm 3$ \\
\hline C. verbanacea & $1.2 \pm 0.1$ & $357 \pm 4$ & $37 \pm 7$ & $9.5 \pm 0.3$ & $142 \pm 3$ & $63 \pm 2$ & $107 \pm 6$ \\
\hline C. longa & $0.12 \pm 0.01$ & $327 \pm 5$ & $90 \pm 12$ & $0.7 \pm .2$ & $193 \pm 5$ & $76 \pm 3$ & $20 \pm 2$ \\
\hline C. citratus & $0.52 \pm 0.08$ & $161 \pm 2$ & $116 \pm 7$ & $6.2 \pm 0.3$ & $163 \pm 4$ & $28 \pm 3$ & $18 \pm 1$ \\
\hline C. scolymus & $1.5 \pm 0.1$ & $720 \pm 9$ & $32 \pm 3$ & $1.9 \pm 0.3$ & $47 \pm 2$ & $2255 \pm 75$ & $47 \pm 3$ \\
\hline E. macrophyllus & $1.4 \pm 0.6$ & $499 \pm 7$ & $27 \pm 6$ & $8.9 \pm 0.1$ & $370 \pm 9$ & $51 \pm 1$ & $102 \pm 6$ \\
\hline E. arvense & $1.2 \pm 0.1$ & $360 \pm 5$ & $48 \pm 5$ & $5.0 \pm 0.1$ & $147 \pm 5$ & $343 \pm 11$ & $23 \pm 3$ \\
\hline E. verna & $1.5 \pm 0.2$ & $364 \pm 5$ & & $5.2 \pm 0.3$ & $79 \pm 3$ & $44 \pm 1$ & $176 \pm 9$ \\
\hline E. globulus & $1.2 \pm 0.2$ & $490 \pm 8$ & $434 \pm 11$ & $6.5 \pm 0.2$ & $809 \pm 16$ & & $99 \pm 6$ \\
\hline E. uniflora & $0.71 \pm 0.09$ & $179 \pm 3$ & $82.82 \pm 0.07$ & $4.0 \pm 0.2$ & $117 \pm 7$ & $51 \pm 5$ & $234 \pm 9$ \\
\hline G. glaba & $0.21 \pm 0.03$ & $151 \pm 2$ & $77.5 \pm 0.3$ & $9.4 \pm 0.3$ & $46 \pm 1$ & $56 \pm 1$ & $20 \pm 1$ \\
\hline H. virginiana & $0.8 \pm 0.1$ & $209 \pm 8$ & $27 \pm 1$ & $5.6 \pm 0.3$ & $396 \pm 10$ & $88 \pm 8$ & $37 \pm 4$ \\
\hline H. procumbens & $0.7 \pm 0.2$ & $849 \pm 10$ & $40 \pm 1$ & $5.0 \pm 0.2$ & $23.5 \pm 0.8$ & $112 \pm 3$ & $98 \pm 4$ \\
\hline I. verum & $0.20 \pm 0.03$ & $187 \pm 7$ & $116 \pm 4$ & $10.8 \pm 0.5$ & $336 \pm 8$ & $100 \pm 3$ & $6 \pm 3$ \\
\hline L. sidoides & $1.1 \pm 0.1$ & $299 \pm 8$ & $70 \pm 1$ & $1.47 \pm 0.07$ & $20.7 \pm 0.6$ & $52 \pm 2$ & \\
\hline M. sylvestris & $1.30 \pm 0.09$ & $1370 \pm 11$ & $81 \pm 2$ & $4.3 \pm 0.2$ & $309 \pm 9$ & $144 \pm 3$ & $187 \pm 6$ \\
\hline M. recutita & $0.49 \pm 0.05$ & $482 \pm 7$ & & $0.9 \pm 0.2$ & $73 \pm 2$ & $140 \pm 5$ & $4 \pm 2$ \\
\hline M. ilicifolia & $2.3 \pm 0.2$ & $103 \pm 2$ & $145 \pm 3$ & $0.7 \pm 0.3$ & $38 \pm 1$ & $19 \pm 2$ & $136 \pm 5$ \\
\hline M. officinales & $2.0 \pm 0.2$ & $174 \pm 4$ & $47 \pm 3$ & $2.7 \pm 0.2$ & $123 \pm 3$ & $54 \pm 1$ & $56 \pm 3$ \\
\hline M. piperita & $2.0 \pm 0.2$ & $1972 \pm 19$ & $98 \pm 5$ & $2.8 \pm 0.3$ & $164 \pm 6$ & $4702 \pm 141$ & $33 \pm 3$ \\
\hline M. pulegium & $1.1 \pm 0.4$ & $12259 \pm 84$ & $34 \pm 2$ & $8.21 \pm 0.06$ & $297 \pm 7$ & $459 \pm 8$ & $116 \pm 5$ \\
\hline M. glomerata & $1.51 \pm 0.09$ & $189 \pm 2$ & $75 \pm 5$ & $2.7 \pm 0.1$ & $1046 \pm 68$ & $1591 \pm 29$ & $13 \pm 1$ \\
\hline M. charantia & $0.76 \pm 0.07$ & $860 \pm 10$ & $94 \pm 5$ & $53.1 \pm 0.4$ & $188 \pm 5$ & $156 \pm 6$ & \\
\hline P. alata & $1.7 \pm 0.1$ & $202 \pm 2$ & $54.8 \pm 0.1$ & $12.8 \pm 0.2$ & $27.2 \pm 0.8$ & $22 \pm 1$ & $156 \pm 6$ \\
\hline P. incarnata & $0.81 \pm 0.08$ & $898 \pm 10$ & $117 \pm 2$ & $4.0 \pm 0.4$ & $1022 \pm 29$ & $88 \pm 2$ & $8 \pm 2$ \\
\hline P. cupana & $0.10 \pm 0.01$ & $111 \pm 1$ & $69 \pm 2$ & $2.7 \pm 0.2$ & $16.6 \pm 0.5$ & $48 \pm 1$ & \\
\hline P. boldus & $1.15 \pm 0.07$ & $308 \pm 3$ & $119 \pm 6$ & $1.2 \pm 0.2$ & $103 \pm 3$ & $239 \pm 4$ & $25 \pm 2$ \\
\hline P. niruri & $0.78 \pm 0.05$ & $1882 \pm 16$ & $74 \pm 1$ & $2.0 \pm 0.1$ & $204 \pm 5$ & $103 \pm 4$ & $54 \pm 3$ \\
\hline P. onisum & $0.88 \pm 0.05$ & $334 \pm 4$ & $13.9 \pm 0.2$ & $13.2 \pm 0.2$ & $39 \pm 1$ & $91 \pm 3$ & $20 \pm 1$ \\
\hline P. major & $1.23 \pm 0.08$ & $3021 \pm 31$ & $62 \pm 10$ & $14.6 \pm 0.3$ & $103 \pm 3$ & $100 \pm 4$ & $63 \pm 5$ \\
\hline P. punctatum & $1.2 \pm 0.2$ & $421 \pm 5$ & $85 \pm 2$ & $7.5 \pm 0.3$ & $132 \pm 3$ & $7718 \pm 167$ & $39 \pm 3$ \\
\hline P. guajava & $2.0 \pm 0.3$ & $154 \pm 5$ & $214 \pm 7$ & $1.5 \pm 0.2$ & $183 \pm 5$ & $85 \pm 3$ & $83 \pm 4$ \\
\hline P. granatum & $0.36 \pm 0.06$ & $68 \pm 2$ & $294 \pm 11$ & $0.45 \pm 0.1$ & $2.4 \pm 0.3$ & $21 \pm 1$ & $33 \pm 2$ \\
\hline R. purshiana & $1.10 \pm 0.07$ & $43 \pm 2$ & $10.70 \pm 0.04$ & $1.5 \pm 0.3$ & $295 \pm 7$ & $78 \pm 4$ & $113 \pm 7$ \\
\hline R. officinales & $0.80 \pm 0.05$ & $313 \pm 6$ & $36.42 \pm 0.01$ & $3.2 \pm 0.2$ & $20 \pm 1$ & $84 \pm 2$ & $15 \pm 2$ \\
\hline S. officinalis & $1.6 \pm 0.2$ & $3370 \pm 39$ & $70 \pm 4$ & $15.9 \pm 0.3$ & $87 \pm 2$ & $219 \pm 13$ & $44 \pm 5$ \\
\hline S. nigra & $0.49 \pm 0.04$ & $381 \pm 4$ & $56 \pm 2$ & $1.2 \pm 0.2$ & $52 \pm 2$ & $144 \pm 4$ & $26 \pm 2$ \\
\hline S. terebinthifolia & $2.1 \pm 0.2$ & $43 \pm 4$ & $10 \pm 5$ & $2.72 \pm 0.08$ & $13.5 \pm 0.5$ & $20 \pm 3$ & $390 \pm 15$ \\
\hline S. alexandrina & $1.3 \pm 0.1$ & $520 \pm 6$ & $222 \pm 11$ & $1.7 \pm 0.1$ & $24.3 \pm 0.8$ & $279 \pm 8$ & $10 \pm 1$ \\
\hline S. paniculatum & $0.53 \pm 0.06$ & $618 \pm 7$ & $204 \pm 1$ & $0.4 \pm 0.3$ & $129 \pm 4$ & $43 \pm 2$ & $116 \pm 4$ \\
\hline St. adstringens & $0.14 \pm 0.02$ & $59 \pm 3$ & $194 \pm 2$ & $0.7 \pm 0.1$ & $6.6 \pm 0.3$ & $12 \pm 2$ & $33 \pm 2$ \\
\hline T. officinalles & $1.1 \pm 0.1$ & $1979 \pm 25$ & $187 \pm 47$ & $2.6 \pm 0.2$ & $128 \pm 4$ & $229 \pm 6$ & $124 \pm 7$ \\
\hline U. tomentosa & $0.28 \pm 0.04$ & $123 \pm 6$ & $73 \pm 15$ & $0.7 \pm 0.1$ & $22 \pm 1$ & $59 \pm 5$ & $17 \pm 3$ \\
\hline$V$. polyanthes & $1.2 \pm 0.2$ & $490 \pm 11$ & $254 \pm 38$ & $1.0 \pm 0.2$ & $389 \pm 9$ & $22 \pm 5$ & $242 \pm 10$ \\
\hline Z. officinale & $0.18 \pm 0.02$ & $109 \pm 2$ & $59 \pm 11$ & $1.2 \pm 0.2$ & $484 \pm 12$ & $64 \pm 2$ & $6.4 \pm 0.8$ \\
\hline Scientific name & $\mathrm{Pb} /\left(\mathrm{mg} \mathrm{kg}^{-1}\right)$ & $\mathrm{Rb} /\left(\mathrm{mg} \mathrm{kg}^{-1}\right)$ & $\mathrm{Se} /\left(\mathrm{mg} \mathrm{kg}^{-1}\right)$ & $\mathrm{Ti} /\left(\mathrm{mg} \mathrm{kg}^{-1}\right)$ & $\mathrm{V} /\left(\mathrm{mg} \mathrm{kg}^{-1}\right)$ & $\mathrm{Zn} /\left(\mathrm{mg} \mathrm{kg}^{-1}\right)$ & \\
\hline A. millefolium & $0.9 \pm 0.2$ & $12.5 \pm 0.4$ & $0.10 \pm 0.04$ & & & $32 \pm 2$ & \\
\hline A. satureioides & $2.8 \pm 0.6$ & $25.3 \pm 0.7$ & $0.17 \pm 0.09$ & $92 \pm 18$ & $0.08 \pm 0.06$ & & \\
\hline A. hippocastanum & $38.2 \pm 0.8$ & $2.9 \pm 0.3$ & & $45 \pm 14$ & $1.0 \pm 0.1$ & $17.5 \pm 0.8$ & \\
\hline A. conyzoides & $6.6 \pm 0.3$ & $32 \pm 1$ & $0.6 \pm 0.2$ & $417 \pm 51$ & $4.9 \pm 0.9$ & $36 \pm 1$ & \\
\hline A. sativum & & $6.0 \pm 0.5$ & & & & $23 \pm 1$ & \\
\hline A. occidentales & $3.9 \pm 0.4$ & $6.8 \pm 0.3$ & $0.19 \pm 0.03$ & $76 \pm 14$ & & $9.8 \pm 0.4$ & \\
\hline A. lappa & $1.8 \pm 0.3$ & $46 \pm 2$ & & & & $23.7 \pm 0.9$ & \\
\hline
\end{tabular}


Table 5. Concentrations and expanded uncertainty $(\mathrm{K}=2)$ obtained in the analyzed samples (cont.)

\begin{tabular}{|c|c|c|c|c|c|c|}
\hline Scientific name & $\mathrm{Pb} /\left(\mathrm{mg} \mathrm{kg}^{-1}\right)$ & $\mathrm{Rb} /\left(\mathrm{mg} \mathrm{kg}^{-1}\right)$ & $\mathrm{Se} /\left(\mathrm{mg} \mathrm{kg}^{-1}\right)$ & $\mathrm{Ti} /\left(\mathrm{mg} \mathrm{kg}^{-1}\right)$ & $\mathrm{V} /\left(\mathrm{mg} \mathrm{kg}^{-1}\right)$ & $\mathrm{Zn} /\left(\mathrm{mg} \mathrm{kg}^{-1}\right)$ \\
\hline A. montana & $0.5 \pm 0.4$ & $97 \pm 4$ & & & & $32 \pm 1$ \\
\hline B. trimera & $10.7 \pm 0.4$ & $129 \pm 5$ & & & & $43 \pm 2$ \\
\hline B. pilosa & $8.5 \pm 0.6$ & $72 \pm 2$ & $0.37 \pm 0.08$ & $0.7 \pm 0.3$ & $0.15 \pm 0.08$ & \\
\hline C. ferrea & $1.02 \pm 0.5$ & $4.8 \pm 0.4$ & & & & $46 \pm 4$ \\
\hline C. officinalis & $0.6 \pm 0.4$ & $83 \pm 3$ & & & & $54 \pm 1$ \\
\hline C. sylvestris & & $34 \pm 1$ & $0.4 \pm 0.1$ & & $0.9 \pm 0.2$ & $25.9 \pm 0.7$ \\
\hline C. verum & $5.6 \pm 0.7$ & $7.1 \pm 0.2$ & $0.13 \pm 0.05$ & & & $10.6 \pm 0.5$ \\
\hline C. auranrium & $7.0 \pm 0.6$ & $13.8 \pm 0.6$ & & & $0.10 \pm 0.04$ & $7.9 \pm 0.4$ \\
\hline C. verbanacea & $5.26 \pm 0.09$ & $27 \pm 1$ & & & $0.6 \pm 0.1$ & $30 \pm 1$ \\
\hline C. longa & $0.7 \pm 0.5$ & $30.5 \pm 0.7$ & & $71 \pm 18$ & & $15.8 \pm 0.7$ \\
\hline C. citratus & $14.7 \pm 0.7$ & $46 \pm 1$ & & & $0.14 \pm 0.05$ & $21.9 \pm 0.8$ \\
\hline C. scolymus & $1.0 \pm 0.8$ & $28.9 \pm 0.7$ & $0.20 \pm 0.09$ & $86 \pm 28$ & & $23.1 \pm 0.8$ \\
\hline E. macrophyllus & $5.3 \pm 0.5$ & $74 \pm 3$ & & & & $24 \pm 1$ \\
\hline E. arvense & & $229 \pm 5$ & & & & $169 \pm 8$ \\
\hline E. verna & $11.8 \pm 0.9$ & $32 \pm 1$ & & & $0.7 \pm 0.2$ & $9.2 \pm 0.6$ \\
\hline E. globulus & $1.6 \pm 0.4$ & $28 \pm 1$ & $0.18 \pm 0.07$ & & $0.53 \pm 0.09$ & $19.7 \pm 0.8$ \\
\hline E. uniflora & $76.9 \pm 0.5$ & $75 \pm 4$ & $0.03 \pm 0.01$ & & & $24.5 \pm 0.6$ \\
\hline G. glaba & $1.5 \pm 0.3$ & $3.7 \pm 0.1$ & $0.04 \pm 0.02$ & & & $8.5 \pm 0.5$ \\
\hline H. virginiana & $5.0 \pm 0.5$ & $3.6 \pm 0.4$ & & & & $16.1 \pm 0.9$ \\
\hline H. procumbens & & $10.1 \pm 0.5$ & & $227 \pm 46$ & $0.5 \pm 0.3$ & $17.3 \pm 0.7$ \\
\hline I. verum & $0.80 \pm 0.05$ & $69 \pm 4$ & & & & $16 \pm 2$ \\
\hline L. sidoides & $2 \pm 1$ & & & $49 \pm 10$ & & $18 \pm 1$ \\
\hline M. sylvestris & $2.3 \pm 0.3$ & $29.0 \pm 0.8$ & $0.20 \pm 0.08$ & $186 \pm 35$ & $2.7 \pm 0.2$ & $67 \pm 2$ \\
\hline$M$. recutita & & $79 \pm 2$ & $0.8 \pm 0.3$ & & $0.5 \pm 0.2$ & $29 \pm 1$ \\
\hline M. ilicifolia & & $68 \pm 3$ & $0.32 \pm 0.07$ & & & $20.5 \pm 0.8$ \\
\hline M. officinales & & $19.2 \pm 0.7$ & & & $0.31 \pm 0.06$ & $33 \pm 2$ \\
\hline M. piperita & $4.3 \pm 0.6$ & $10.4 \pm 0.5$ & & $178 \pm 39$ & $6 \pm 1$ & $19.4 \pm 0.8$ \\
\hline M. pulegium & $4.6 \pm 0.6$ & $23.7 \pm 0.7$ & & $644 \pm 59$ & $5.5 \pm 0.4$ & $48 \pm 1$ \\
\hline M. glomerata & $0.7 \pm 0.5$ & $176 \pm 5$ & & & & $30.5 \pm 0.9$ \\
\hline M. charantia & $49.2 \pm 0.6$ & $19.3 \pm 0.8$ & & $34 \pm 14$ & $0.6 \pm 0.1$ & $34 \pm 1$ \\
\hline P. alata & $1.2 \pm 0.7$ & $73 \pm 2$ & $0.17 \pm 0.05$ & $22 \pm 19$ & $0.12 \pm 0.06$ & $40 \pm 1$ \\
\hline P. incarnata & & $49 \pm 2$ & $0.6 \pm 0.1$ & & $1.4 \pm 0.4$ & $44 \pm 1$ \\
\hline P. cupana & $1.2 \pm 0.5$ & $23.0 \pm 0.6$ & $0.15 \pm 0.03$ & & $0.19 \pm 0.03$ & $20.9 \pm 0.6$ \\
\hline P. boldus & & $14.7 \pm 0.4$ & $0.23 \pm 0.09$ & & $1.0 \pm 0.2$ & $15.1 \pm 0.5$ \\
\hline P. niruri & $1.2 \pm 0.4$ & $8.8 \pm 0.4$ & & $440 \pm 63$ & $7.1 \pm 0.5$ & $40.6 \pm 0.9$ \\
\hline P. onisum & $13.4 \pm 0.7$ & & $0.26 \pm 0.05$ & & $0.12 \pm 0.07$ & $40 \pm 2$ \\
\hline P. major & & $41 \pm 2$ & & $87 \pm 30$ & $5.3 \pm 0.7$ & $26 \pm 1$ \\
\hline P. punctatum & $7.3 \pm 0.2$ & $24.8 \pm 0.9$ & & & $0.6 \pm 0.1$ & $35 \pm 2$ \\
\hline P. guajava & $2.3 \pm 0.1$ & $13.2 \pm 0.6$ & & & & $50 \pm 2$ \\
\hline P. granatum & & $37 \pm 1$ & $0.55 \pm 0.09$ & & & $8.0 \pm 0.5$ \\
\hline R. purshiana & $0.9 \pm 0.4$ & $11.4 \pm 0.5$ & $0.18 \pm 0.07$ & & & $7.4 \pm 0.3$ \\
\hline R. officinales & $3 \pm 1$ & $2.6 \pm 0.2$ & $0.15 \pm 0.03$ & & & \\
\hline S. officinalis & $12.7 \pm 0.5$ & $3.7 \pm 0.5$ & & $636 \pm 48$ & $8.2 \pm 0.9$ & $102 \pm 9$ \\
\hline S. nigra & $2.9 \pm 0.3$ & $11.0 \pm 0.4$ & $0.5 \pm 0.1$ & $193 \pm 66$ & & $42 \pm 2$ \\
\hline S. terebinthifolia & $2.3 \pm 0.3$ & $6.0 \pm 0.4$ & & & & $10 \pm 1$ \\
\hline S. alexandrina & $1.6 \pm 0.6$ & $7.1 \pm 0.3$ & $1.1 \pm 0.1$ & $97 \pm 16$ & & $10.7 \pm 0.4$ \\
\hline S. paniculatum & $2.1 \pm 0.3$ & $28 \pm 1$ & & & & $23.3 \pm 0.7$ \\
\hline St. adstringens & $0.9 \pm 0.3$ & $7.9 \pm 0.3$ & $0.17 \pm 0.06$ & & & $18 \pm 1$ \\
\hline T. officinalles & $1.5 \pm 0.1$ & $105 \pm 4$ & & $338 \pm 36$ & $7 \pm 2$ & $63 \pm 6$ \\
\hline U. tomentosa & & $17.9 \pm 0.8$ & & & $0.34 \pm 0.05$ & $24 \pm 2$ \\
\hline V. polyanthes & $20.3 \pm 0.3$ & $53 \pm 2$ & $0.6 \pm 0.2$ & $46 \pm 23$ & $0.7 \pm 0.1$ & $131 \pm 11$ \\
\hline Z. officinale & $1.7 \pm 0.9$ & $3.9 \pm 0.2$ & $0.60 \pm 0.06$ & & & $23.1 \pm 0.9$ \\
\hline
\end{tabular}


used as raw material, in concentrations of 1.0, 0.3 and $10 \mathrm{mg} \mathrm{kg}^{-1}$. Observing the data in Table 5, it can be noted that this value exceeded by $15 \%$ of the samples for $\mathrm{Pb}$, by $5 \%$ of the samples for $\mathrm{Cd}$ and in no sample for As.

Mentha pulegium showed the highest concentrations for the elements $\mathrm{Co}, \mathrm{Fe}, \mathrm{Sc}$ and $\mathrm{Ti}$ and relatively high concentrations for the elements $\mathrm{Ba}, \mathrm{Cr}, \mathrm{Cs}, \mathrm{Hf}, \mathrm{Na}, \mathrm{Sb}, \mathrm{V}$, $\mathrm{Zn}$; Taraxacum officinale showed the highest concentration for As and relatively high concentrations for $\mathrm{Ba}, \mathrm{Br}, \mathrm{Co}$, $\mathrm{Cs}, \mathrm{Fe}, \mathrm{Hf}, \mathrm{Hg}, \mathrm{Rb}, \mathrm{Sc}, \mathrm{Ti}, \mathrm{V}, \mathrm{Zn}$; Salvia officinalis showed the highest concentrations for the elements $\mathrm{Cu}$, Hf and $\mathrm{V}$ and relatively high concentrations for $\mathrm{Ca}, \mathrm{Co}, \mathrm{Cs}, \mathrm{Fe}$, $\mathrm{Hf}, \mathrm{Mg}, \mathrm{Ni}$, Sb, Sc, Ti, Zn; Agerantum conyzoides showed the highest concentrations for $\mathrm{Mg}$ and relatively high concentrations for $\mathrm{Ba}, \mathrm{Br}, \mathrm{Co}, \mathrm{Fe}, \mathrm{Na}, \mathrm{Sb}, \mathrm{Sc}, \mathrm{Ti}, \mathrm{V}$; the highest concentration of $\mathrm{Cd}, \mathrm{Pb}$ and $\mathrm{Hg}$ was observed in the samples of Vernonia polyanthes, Eugenia uniflora and Eucalyptus globulus, respectively. High concentrations were also observed in Malva sylvestris for $\mathrm{Ba}, \mathrm{Br}, \mathrm{Cr}, \mathrm{Fe}$, $\mathrm{Hf}, \mathrm{K}, \mathrm{Mg}, \mathrm{Sc}, \mathrm{Ti}, \mathrm{V}$ and $\mathrm{Zn}$ and in Passiflora incarnate, for $\mathrm{Br}, \mathrm{Cr}, \mathrm{Cs}$, Fe, Hf, $\mathrm{Hg}$, Sb, Sc, Se, Mn and Zn.

Low concentrations for the majority of the determined elements were, generally, measured in the samples of Allium sativum, Calendula officinalis, Casearia sylvestris, Cinnamomum verum, Citrus auranrium, Glycyrrhiza glaba, Illicium verum, Maytenus ilicifolia, Psidium guajava and Punica granatum.

\section{Major elements}

Calcium is an essential element for plants and its content varied from 0.035 to $2.4 \%$ in the samples of Allium sativum and Caesalpinia ferrea, respectively. Low $\mathrm{Ca}$ concentrations were also found in the literature for Allium sativum ${ }^{21}$ and high concentrations, varying from 1.5 to $2.0 \%,,^{7,22}$ have been found in Glycyrrhiza glabra and Malva sylvestris. Compared with our results, the highest values are in the same order of magnitude and the lowest are well below the reported figures. Potassium, an essential element that is generally supplied to plants by means of fertilization processes also showed a wide variation with a higher value found in Echinodorus macrophyllus. In the plants with this element, the concentrations determined ranged from 0.16 to $7.4 \%$. Magnesium, besides being a chlorophyll component is also an enzyme co-factor. ${ }^{23}$ Its concentration varied from below LOD up to $1.14 \%$ in the sample of Agerantum conyzoides and these values are in good agreement with the literature, registering concentrations which vary from 0.0004 to $2.3 \%$ in Melissa officinales and Matricaria recutita samples, respectively. ${ }^{22,24}$ Another essential element for plants,
$\mathrm{Cl}$ concentrations varied from below LOD up to $1.8 \%$ in the Equisetum arvense sample.

\section{Minor elements}

Iron and manganese are essential elements for plant protein synthesis. ${ }^{25}$ Allium sativum was the sample with the lowest Fe value, while the highest was registered in the Mentha pulegium sample: the range of variation for this element was from 26 to $12259 \mathrm{mg} \mathrm{kg}^{-1}$, respectively. The range of $\mathrm{Fe}$ concentrations, found in the literature, ${ }^{26,27}$ vary from 6.7 to $1787 \mathrm{mg} \mathrm{kg}^{-1}$, considering the same plant species included in this study. Manganese concentrations varied from 2.4 to $1046 \mathrm{mg} \mathrm{kg}^{-1}$ in Punica granatum and Mikania glomerata, respectively.

Copper is a micronutrient and an essential enzymatic element for normal plant growth and development, but it can be toxic at excessive levels and it is a harmful element for human health. ${ }^{28}$ The concentrations here obtained varied from 1.88 to $24.5 \mathrm{mg} \mathrm{kg}^{-1}$ in samples of Rhamnus purshiana and Salvia officinalis, respectively. These values are in well agreement with those found in the literature, which vary from $0.1 \mathrm{mg} \mathrm{kg}^{-1}$ in Zingirber officinale up to $27.4 \mathrm{mg} \mathrm{kg}^{-1}$ in Plantago major, ${ }^{29,30}$ although higher concentrations, up to $177 \mathrm{mg} \mathrm{kg}^{-1}$, had been reported for Aesculus hippocastanum leaves. ${ }^{31} \mathrm{Ni}$ concentrations varied from $0.4 \mathrm{mg} \mathrm{kg}^{-1}$ in Allium sativum to $53 \mu \mathrm{g} \mathrm{kg}^{-1}$ in Momordica charantia samples. It was observed that the concentration of this element, for most of the species, were in agreement with values found in the literature, ${ }^{32,33}$ varying from 0.32 to $6.7 \mu \mathrm{g} \mathrm{kg}^{-1}$ in samples of Cinnamomum verum and Anacardium occidentales, respectively, although approximately one quarter of the samples showed an enrichment for this metal. Zinc is an essential element for plants and animals whose biological functions can be catalytic, structural or regulatory. In this study, $\mathrm{Zn}$ concentrations varied from $7.4 \mathrm{mg} \mathrm{kg}^{-1}$ in Rhamnus purshiana to $169 \mathrm{mg} \mathrm{kg}^{-1}$ in Equisetum arvense samples. The literature ${ }^{34,35}$ reported values showing variations ranging from 0.86 to $168 \mathrm{mg} \mathrm{kg}^{-1}$ in Aesculus hippocastanum and Bidens pilosa, respectively.

\section{Other trace elements}

Barium was found in the range of 2 to $390 \mathrm{mg} \mathrm{kg}^{-1}$ in Cinnamomum verum and Schinus terebinthifolia, respectively. Reported concentrations ${ }^{32,36}$ vary from 2 to $100 \mathrm{mg} \mathrm{kg}^{-1}$, indicating that some of the herbs here analyzed are enriched with this element. Enrichment in some herbs can also be observed for Br. For this reported concentrations ${ }^{37,38}$ vary from 2 to $45 \mathrm{mg} \mathrm{kg}^{-1}$ and, in the samples analyzed in this 
study, varied from 0.7 to $168 \mathrm{mg} \mathrm{kg}^{-1}$, for Illicium verum and Echinodorus macrophyllus, respectively. The values found for Se in the literature ${ }^{33,37}$ range from 76 to $500 \mu \mathrm{g} \mathrm{kg}^{-1}$, in samples of Anacardium occidentale and Curcuma longa, while the values obtained in this study ranged from 31 to $1100 \mu \mathrm{g} \mathrm{kg}^{-1}$ in Eugenia uniflora and Senna alexandrina, also, indicating a Se enrichment in the present samples.

Concentrations of Co varying from 69 to $9100 \mu \mathrm{g} \mathrm{kg}^{-1}$ were found in our samples, with the lowest values in Passiflora alata and the highest in Mentha pulegium while reported values ranges from 17 to $1200 \mu \mathrm{g} \mathrm{kg}^{-1}$ in Allium sativum and Malva sylvestris, respectively. ${ }^{22,37}$ Chromium(VI), which is a by-product of numerous industrial processes, is recognized as a carcinogen when inhaled and $\mathrm{Cr}^{\mathrm{III}}$ is the most stable oxidation state and, presumably, the form that is present in food supply, due to the presence of reducing substances. ${ }^{39}$ The levels of $\mathrm{Cr}$ in our samples ranged from 0.5 to $256 \mathrm{mg} \mathrm{kg}^{-1}$ in the samples of Paulinia cupana and Aesculus hippocastanum, respectively: some samples showed higher values than those found in the literature, ${ }^{33,40}$ which ranged from 0.012 to $115 \mathrm{mg} \mathrm{kg}^{-1}$ in samples of Anacardium occidentale and Casearia sylvestris, respectively.

Very few values have been reported in the literature for $\mathrm{Cs}, \mathrm{Hf}, \mathrm{Rb}, \mathrm{Sb}, \mathrm{Sc}, \mathrm{Ti}$ and $\mathrm{V}$ in the same species here analyzed.

The elements $\mathrm{Rb}, \mathrm{Sc}$ and $\mathrm{Sb}$ were found in the range of 2.6 to $229,1.2$ to 3660 and 5 to $90 \mu \mathrm{g} \mathrm{kg}^{-1}$, respectively. The reported values in the literature are 2 to $80,,^{41,40} 0.14$ to $10.3^{25,40}$ and 0.4 to $20000 \mu \mathrm{g} \mathrm{kg}^{-1}, 33,34$ respectively. The plants with higher concentrations for these elements, observed in this study, were Equisetum arvense for $\mathrm{Rb}$ and $\mathrm{Sb}$ and Mentha pulegium for Sc. As to the values found in the literature, Casearia sylvestris showed the highest concentration of $\mathrm{Rb}$ and $\mathrm{Sc}^{40}$ and Equisetum arvense of $\mathrm{Sb}^{35}$ Vanadium concentrations were found varying between below LOD up to $8.2 \mu \mathrm{g} \mathrm{kg}^{-1}$ in the sample of Salvia officinalis, what was consistent with those values found in the literature. The results obtained for Ti showed enrichment in some of the medicinal plants here analyzed with concentrations reaching values up to $644 \mu \mathrm{g} \mathrm{kg}^{1}$, once a range varying from 1.4 to $57 \mu \mathrm{g} \mathrm{kg}^{-1}$ was verified for plants of the same species. ${ }^{22,25}$

Cesium was found in values up to $1.19 \mathrm{mg} \mathrm{kg}^{-1}$ in Curcuma longa ${ }^{37}$ and compared to our samples about half of the plants, in which this element was measured, contain higher levels of this element. A concentration of $53 \mu \mathrm{g} \mathrm{kg}^{-1}$ is registered for $\mathrm{Hf}$ in Anacardium occidentale and this value is much lower than that encountered in almost all the herbs here analyzed.

\section{Potentially hazardous elements}

Arsenic was measured only in a small number of samples with concentrations varying from $0.05 \mu \mathrm{g} \mathrm{kg}^{-1}$, in Psidium guajava, to $0.59 \mu \mathrm{g} \mathrm{kg}^{-1}$ in Taraxacum officinalles species, respectively.

The chronic toxicity of $\mathrm{Cd}$ to humans has been documented with cases of poisoning from herbal products in India, China, Brazil, Argentina and Mexico. ${ }^{42}$ Short term effects include nausea, vomiting, diarrhea and cramps. ${ }^{43}$ In the present samples, Cd concentrations varied from below LOD up to $0.55 \mu \mathrm{g} \mathrm{g}^{-1}$, in the sample of Vernonia polyanthes. Low level of this element was found ${ }^{44}$ in Curcuma longa, $0.004 \mu \mathrm{g} \mathrm{g}^{-1}$, and the highest amount was found ${ }^{45}$ in Taraxacum officinalles, $7.24 \mu \mathrm{g} \mathrm{g}^{-1}$, considering the plants included in this paper.

Very few data about $\mathrm{Hg}$ are found in medicinal plants and values from 0.065 up to $54 \mu \mathrm{g} \mathrm{kg}^{-1}$ were reported ${ }^{29,46}$ for Salvia officinalis and Momordica charantia, respectively. Among the samples analyzed in this work, almost all of them showed measurable amounts of this element and the concentrations varied from 2.5 to $434 \mu \mathrm{g} \mathrm{kg}^{-1}$, in Aesculus hippocastanum and Eucalyptus globulus samples, respectively, indicating an one order of magnitude enrichment for this element, when compared to that found in foods other than fish products that, generally, varies between 1 and $50 \mu \mathrm{g} \mathrm{kg}^{-1}$.

Lead is a non-essential element, but it is found widespread in the environment. In the present samples, its concentration varied from below LOD to $76.9 \mathrm{mg} \mathrm{kg}^{-1}$ in the Eugenia uniflora sample. The literature registers values up to $1544 \mathrm{mg} \mathrm{kg}^{-1}$ for this element in plants belonging to the same set of those here analyzed..$^{42}$ It is worth noting that nine of our samples showed values higher than the permitted by WHO for this element.

\section{Elemental distribution pattern}

In Figure 1, the mean concentration distribution, according to the part of the plant used as medicine, is shown. The elements were distributed in the figure according to their magnitude. It can be seen that shoots showed high concentrations for the elements $\mathrm{Br}, \mathrm{Cl}, \mathrm{Co}, \mathrm{Cr}$, $\mathrm{Cs}, \mathrm{Fe}, \mathrm{Hf}, \mathrm{Mg}, \mathrm{Mn}, \mathrm{Na}, \mathrm{Rb}, \mathrm{Sb}, \mathrm{Sc}, \mathrm{Ti}, \mathrm{V}, \mathrm{Zn}$ and for the potentially toxic $\mathrm{Cd}$. When the whole plant was analyzed high concentrations was verified for the elements $\mathrm{Ba}, \mathrm{Br}$, $\mathrm{Fe}, \mathrm{Hf}, \mathrm{K}, \mathrm{Rb}, \mathrm{Sc}, \mathrm{Ti}, \mathrm{V}, \mathrm{Zn}$ and $\mathrm{Cu}$ and for the potentially toxic As and $\mathrm{Hg}$. It can also be verified that seeds showed high concentrations for the elements $\mathrm{Ba}, \mathrm{Co}, \mathrm{Cr}, \mathrm{Cu}, \mathrm{Ni}$ and $\mathrm{Pb}$; rhizome samples showed high concentrations for the elements As, Mn and Se and inflorescence, for the 
elements $\mathrm{Ca}, \mathrm{Cl}, \mathrm{Mg}, \mathrm{Na}$ and $\mathrm{Cu}$; fruits showed high values of mean concentrations for $\mathrm{Se}, \mathrm{Hg}$ and $\mathrm{Ni}$; leaves showed high concentrations for $\mathrm{Hg}$ and $\mathrm{Pb}$; flowers, for $\mathrm{Cr}$ and $\mathrm{Cd}$; beans, for $\mathrm{Ca}$ and $\mathrm{Zn}$ and, finally, barks showed higher $\mathrm{Cd}$ concentrations.

The role of essential and non elements in the plant parts analyzed in this study is beyond the scope of this paper but the distribution pattern observed must be related to the plant metabolism and the availability of these elements for transfer from soil to plant. ${ }^{47}$ Also, it is increasingly recognized that the availability of a given micronutrient or contaminant varies substantially in relation to the different chemical species present, ${ }^{48,49}$ being this elemental speciation, among other factors, a function of soil mineralogy, $\mathrm{pH}$ and redox potential. ${ }^{50}$ Another possible contribution source is the pollution of air, soil, and water that arose from the industrial growth and from the agricultural practices that have caused the environmental dispersion of these elements, including the potentially toxic ones, resulting in their entry into food chains, including the
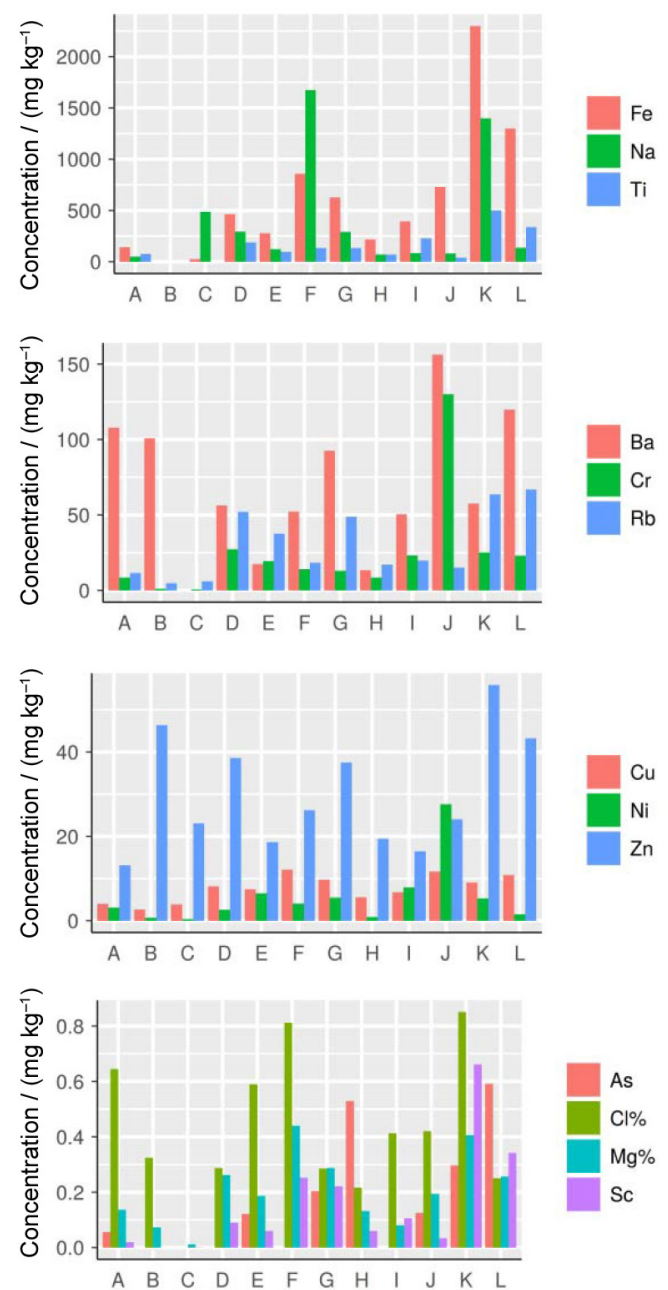

medicinal plants..$^{51} \mathrm{~A}$ remarkable challenge in this field is, therefore, to estimate the anthropogenic contribution for the observed concentrations.

Since the concentration of all the elements varies widely in the analyzed parts of the plants, the main implication of this variation must be that their bioavailability will also vary for consumption depending on the solvent and preparation mode.

\section{Enrichment factor}

Enrichment factor (EF) analysis is generally used to assess anthropogenic contribution to the environment. ${ }^{52,53}$ EF represents the ratio between a given element $\left(E_{i}\right)$ and a conservative element $\left(E_{r}\right)$ in the sample normalized by the same ration, in a geological reference. Generally, the upper continental crust (UCC) is used as the geological reference and the formula is given as $\mathrm{EF}=\left(\mathrm{E}_{\mathrm{i}} / \mathrm{E}_{\mathrm{r}}\right) \operatorname{sample} /\left(\mathrm{E}_{\mathrm{i}} / \mathrm{E}_{\mathrm{r}}\right)_{\mathrm{UCC}}$. Magnesium was chosen as the conservative element, since it is both ubiquitous and an essential element for plants.
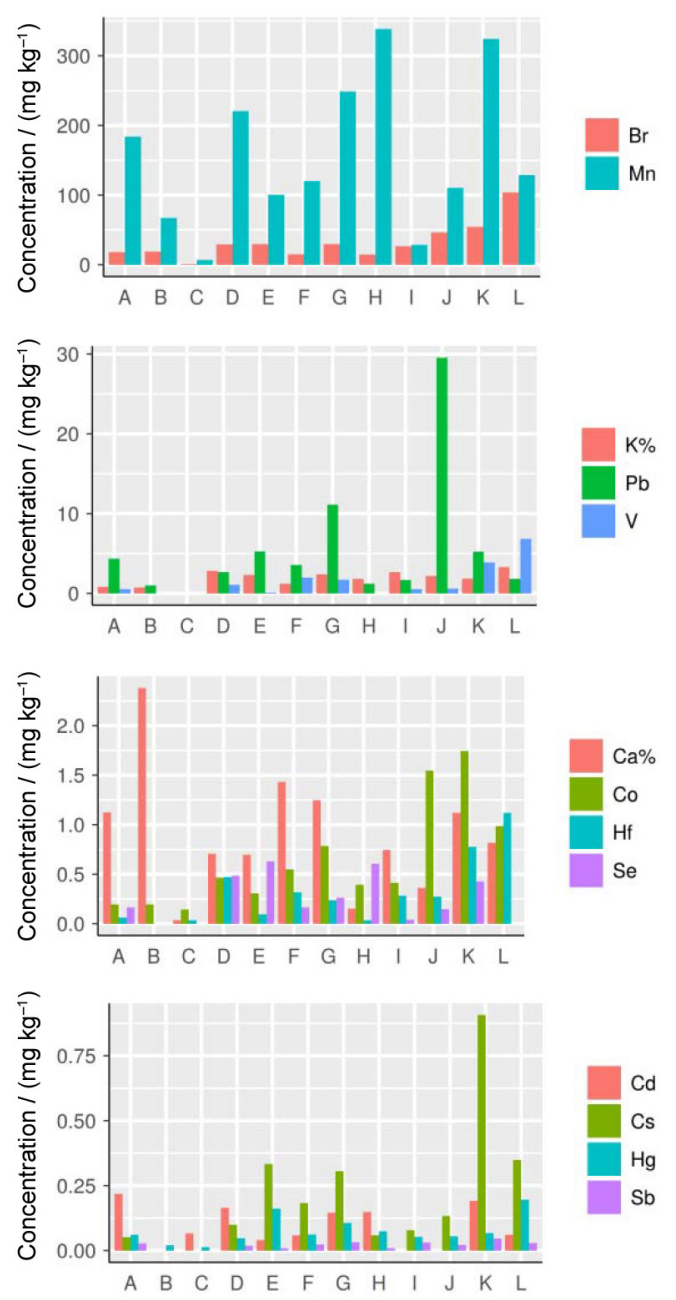

Figure 1. Mean concentration, in $\mathrm{mg} \mathrm{kg}^{-1}$, except were indicated \%, according to the part of the plant, A (bark), B (bean), C (bulb), D (flower), E (fruit), F (inflorescence), G (leaves), H (rizome), I (roots), J (seeds), K (shots), and L (whole plant). 
The calculated EF values for the present samples showed a large variation, ranging from 0.01 up to 500 and were categorized in three groups: (i) $\mathrm{EF}<1$ : As, $\mathrm{Ba}, \mathrm{Co}$, $\mathrm{Cs}, \mathrm{Fe}, \mathrm{Hf}, \mathrm{Na}$, Sb, Sc, Ti, V and Ni; (ii) $1<\mathrm{EF}<10$ : Ca, $\mathrm{Cr}, \mathrm{K}, \mathrm{Mn}, \mathrm{Rb}, \mathrm{Zn}, \mathrm{Cu}$ and $\mathrm{Pb}$; (iii) $\mathrm{EF}>10 \mathrm{Br}, \mathrm{Cl}, \mathrm{Se}$, $\mathrm{Hg}$, and $\mathrm{Cd}$.

The first group is composed, mainly, by non-essential trace elements, that are generally transferred to plants in amounts smaller than the essential ones. The presence of $\mathrm{Fe}$, as well as of $\mathrm{V}$, in this group can be explained because they are major components of the soil. ${ }^{54}$ Most of the essential elements for plants were categorized in the second group, that also include the potentially toxic, $\mathrm{Pb}$. These elements tend to be enriched in the plants up to two orders of magnitude related to the non-essential elements. ${ }^{55,56}$ Although being a non-essential element $\mathrm{Rb}$ was included in this group possibly due to its ionic radius close to the $\mathrm{K}$ radius. ${ }^{54}$ The third group contains, besides the halogens, the potentially hazardous elements $\mathrm{Se}, \mathrm{Hg}$ and $\mathrm{Cd}$.

It was, also, verified that high EF values, for the majority of the elements, were observed, mainly, in the roots and bark, while the potentially toxic elements are mainly enriched in barks. This enrichment for the elements of the third group may possibly reflect some anthropogenic contribution, since they are not essential elements and their mean EF values were up to three orders of magnitude greater than the values obtained for the elements of the other groups and also that its own values obtained in other parts of the plants.

\section{Conclusions}

This study presents the results obtained for 59 medicinal plants commonly used in Brazil. Impurities were found in $50 \%$ of the samples, most of them in parts of plants not used for medicinal purposes; moisture levels varied up to $12 \%$. The elemental concentrations varied in a wide range for almost all the determined elements, with a variation coefficient ranging from 50 to $245 \%$. The species in which relatively high concentrations were measured were Mentha pulegium, Taraxacum officinale, Malva sylvestris, Salvia officinalis, Passiflora incarnateand, Agerantum conyzoides, while low concentrations were found in the Allium sativum, Calendula officinalis, Casearia sylvestris, Cinnamomum verum, Citrus auranrium, Glycyrrhiza glaba, Illicium verum, Maytenus ilicifolia, Psidium guajava and Punica granatum samples.

Good agreement was found between the results obtained in this work and the level of elements reported in the literature, although higher values for some elements such as $\mathrm{Ba}, \mathrm{Cr}, \mathrm{Fe}, \mathrm{Hg}$, Se and Ni were found in some samples.
It was observed that the pattern of elemental distribution varies according to the part of the plant analyzed. Nonessential elements tend to show a low enrichment factor, generally, inferior to 1, while essential elements show EF between 1 and 10. Higher EF values include the potentially hazardous elements $\mathrm{Hg}$ and $\mathrm{Cd}$, mainly, in the bark of the plants, possibly indicating anthropogenic contribution.

\section{Acknowledgments}

Research supported, under fellowship contracts 2011/06768-2 and 2011/06827-9, by the São Paulo State Research Support Foundation (Fundação de Amparo à Pesquisa do Estado de São Paulo-FAPESP), to whom the authors are grateful and to Prof Mario Olimpio Menezes for the help with the graphics.

\section{References}

1. World Health Organization (WHO); Traditional Medicine Strategy: 2014-2023. http://apps.who.int/iris/ bitstream/10665/92455/1/9789241506090_eng.pdf, accessed in April 2016.

2. Thomson, G. E.; J. Med. Plants Res. 2010, 4, 125.

3. Kalaivanan, C.; Chandrasekaran, M.; Venkatesalu, V.; J. Mycol. Med. 2013, 23, 247.

4. Calvo, M. I.; Akerreta, S.; Cavero, R. Y.; Eur. J. Integr. Med. 2013, 5, 537.

5. Maslennikov, P. V.; Chupakhina, G. N.; Skrypnik, L. N.; Biol. Bull. 2014, 41, 133.

6. World Health Organization (WHO); WHA62.13, Sixty-Second World Health Assembly, Geneva, 18-22 May 2009, Resolutions and Decisions, Annexes; WHO Publications: Geneva, 2009. WHA62/2009/REC/1; http://apps.who.int/gb/ebwha/pdf_files/ WHA62-REC1/WHA62_REC1-en.pdf, accessed in April 2016.

7. Łozak, A.; Sołtyk, K.; Ostapczuk, P.; Fijałek, Z.; Sci. Total Environ. 2002, 289, 33.

8. Sattar, S. A.; Reddy, B. S.; Rao, V. K.; Pradeep, A. S.; Raju, G. J. N.; Ramanarayana, K.; Rao, P. V. M.; Reddy, S. B.; J. Radioanal. Nucl. Chem. 2012, 294, 337.

9. Fei, T.; Dehong, L.; Fengqun, Z.; Junhua, L.; Hua, T.; Xiangzhong, K.; J. Radioanal. Nucl. Chem. 2010, 284, 507.

10. Ebrahim, A. M.; Eltayeb, M. H.; Khalid, H.; Mohamed, H.; Abdalla, W.; Grill, P.; Michalke, B.; J. Nat. Med. 2012, 66, 671.

11. Ranđelović, S. S.; Kostić, D. A.; Zarubica, A. R.; Mitić, S. S.; Mitić, M. N.; Hem. Ind. 2013, 67, 585.

12. Bolzani, V. S.; Castro-Gamboa, I.; Silva, D. H. S. In Comprehensive Natural Products II Chemistry and Biology, Vol. 3; Verpoorte, R., ed.; Elsevier: Oxford, UK, 2010, ch. 3.05, p. 95 . 
13. Ermidou-Pollet, S.; Pollet, S.; Cell Biol. Toxicol. 2008, $24,341$.

14. World Health Organization (WHO); Quality Control Methods for Medicinal Plants Materials; http://apps.who.int/iris/ bitstream/10665/41986/1/9241545100.pdf, accessed in April 2016.

15. Oladipo, M. O. A.; Njinga, R. L.; Baba, A.; Muhammad, H. L.; Appl. Radiat. Isot. 2012, 70, 917.

16. Fatima, I.; Waheed, S.; Zaidi, J. H.; Appl. Radiat. Isot. 2013 , $71,57$.

17. Nedjimi, B.; Beladel, B.; J. Appl. Res. Med. Aromat. Plants 2015, 2, 203.

18. Shirisha, K.; Sahrawat, K. L.; Devi, B. P.; Wani, S. P.; Commun. Soil Sci. Plant Anal. 2014, 45, 2201.

19. Farmacopeia Brasileira, Vol. 2; Agência Nacional de Vigilância Sanitária, ANVISA: Brasília, 2010.

20. Lagad, R. A.; Alamelu, D.; Acharya, R.; Aggarwal, S. K.; J. Radioanal. Nucl. Chem. 2011, 288, 613.

21. Méndez, C. M. V.; Rodriguez, E. M. R.; Romero, C. D.; Gonález, M. C. M.; Isasa, M. E. T.; Int. J. Food Sci. Nutr. 2008, 59, 660.

22. Hiçsönmez, Ü.; Ereeş, F. S.; Özdemir, C.; Özdemir, A.; Çam, S.; Biol. Trace Elem. Res. 2009, 128, 248.

23. Bybordi, A.; Shabanov, J. A.; Not. Sci. Biol. 2010, $2,81$.

24. Petenatti, M. E.; Petenatti, E. M.; del Vitto, L. A.; Téves, M. R.; Caffini, N. O.; Marchevsky, E. J.; Pellerano, R. G.; Braz. J. Pharmacog. 2011, 21, 1144.

25. Hänsch, R.; Mendel, R. R.; Curr. Opin. Plant Biol. 2009, 12, 259.

26. Lamari, Z.; Landsberger, S.; Braisted, J.; Neggache, H.; Larbi, R.; J. Radioanal. Nucl. Chem. 2008, 276, 95.

27. Sinha, S.; Gupta, A. K.; Bhatt, K.; Pandey, K.; Rai, U. N.; Singh, K. P.; Environ. Monit. Assess. 2006, 115, 1.

28. Yruela, I.; Braz. J. Plant Physiol. 2005, 17, 145.

29. Alwakeel, S. S.; Res. J. Microbiol. 2008, 3, 683.

30. Siromlya, T. I.; Contemp. Probl. Ecol. 2011, 4, 499.

31. Kim, N. D.; Fergusson, J. E.; Environ. Pollut. 1994, 86, 89.

32. Karadaş, C.; Kara, D.; Food Chem. 2012, 130, 196.

33. Rodushkin, I.; Engström, E.; Sörlin, D.; Baxter, D.; Sci. Total Environ. 2008, 392, 290.

34. Robinson, B. H.; Bischofberger, S.; Stoll, A.; Schroer, D.; Furrer, G.; Roulier, S.; Gruenwald, A.; Attinger, W.; Schulin, R.; Environ. Pollut. 2008, 153, 668.

35. Tomašević, M.; Vukmirović, Z.; Rajšić, S.; Tasić, M.; Stevanović, B.; Chemosphere 2005, 61, 753.

36. Oliva, S. R.; Valdés, B.; Mingorance, M. D.; Food Chem. Toxicol. 2008, 46, 65.

37. Singh, V.; Garg, A. N.; Food Chem. 2006, 94, 81.
38. Gowrishankar, R.; Kumar, M.; Menon, V.; Divi, S. M.; Saravanan, M.; Magudapathy, P.; Panigrahi, B. K.; Nair, K. G. M.; Venkataramaniah, K.; Biol. Trace Elem. Res. 2010, 133, 357.

39. World Health Organization (WHO); Guidelines for DrinkingWater Quality, Vol. 2, 2 ${ }^{\text {nd }}$ ed.; WHO Publications: Geneva, 1996. http://www.who.int/water_sanitation_health/dwq/chemicals/ chromium.pdf, accessed in April 2016.

40. Yamashita, C. I.; Saiki, M.; Vasconcellos, M. B. A.; Serti, J. A. A.; Appl. Radiat. Isot. 2005, 63, 841.

41. Khuder, A.; Sawan, M. Kh.; Karjou, J.; Razouk, A. K; Spectrochim. Acta, Part B 2009, 64, 721.

42. Arpadjan, S.; Çelik, G.; Taşkesen, S.; Güçer, Ş.; Food Chem. Toxicol. 2008, 46, 2871.

43. Bedoui, K.; Abbes-Bekri, I.; Srasra, E.; Desalination 2008, 223 , 269.

44. Meena, A. K.; Bansal, P.; Kumar, S.; Rao, M. M.; Garg, V. K.; Environ. Monit. Assess. 2010, 170, 657.

45. Gjorgieva, D.; Kadifkova-Panovska, T.; Bacěva, K.; Stafilov, T.; Arch. Environ. Contam. Toxicol. 2011, 60, 233.

46. Choudhury, R. P.; Acharya, R.; Nair, A. G. C.; Reddy, A. V. R.; Garg, A. N.; J. Radioanal. Nucl. Chem. 2008, 276, 85.

47. Lombi, E.; Scheckel, K. G.; Kempson, I. M.; Environ. Exp. Bot. 2011, 72, 3.

48. Nolan, A. L.; Lombi, E.; McLaughlin, M. J.; Aust. J. Chem. 2003, 56, 77.

49. Scheckel, K. G.; Chaney, R. L.; Basta, N. T.; Ryan, J. A.; Adv. Agron. 2009, 104, 1.

50. Abedin, M. J.; Feldmann, J.; Meharg, A. A.; Plant Physiol. 2002, 128, 1120.

51. Awodele, O.; Popoola, T. D.; Amadi, K. C.; Coker, H. A. B.; Akintonwa, A.; J. Ethnopharmacol. 2013, 150, 614.

52. Szczepaniak, K.; Biziuk, M.; Environ. Res. 2003, 93, 221.

53. Aničić, M.; Spasić, T.; Tomašević, M.; Rajšić, S.; Tasić, M.; Ecol. Indic. 2011, 11, 824.

54. Uchida, S.; Tagami, K.; Hirai, I.; J. Nucl. Sci. Technol. 2007, 44, 628 .

53. Bargagli, R.; Trace Elements in Terrestrial Plants: an Ecophysiological Approach to Biomonitoring and Biorecovery; Springer-Verlag: Berlin, Heidelberg, NY, 1998.

56. Markert, B.; Instrumental Element and Multi-Element Analysis of Plant Samples; John Wiley \& Sons: Chichester, 1996.

Submitted: December 17, 2015

Published online: April 26, 2016

FAPESP has sponsored the publication of this article. 